\title{
Disinfection of explants for saffron (Crocus sativus) tissue culture
}

\author{
Jaime A. Teixeira da Silva ${ }^{1 a}$, Dariusz Kulus ${ }^{2 b}$, Xinhua Zhang ${ }^{3 c}$, Songjun Zeng ${ }^{3 d}$, \\ Guohua Ma ${ }^{3 e}$, Abel Piqueras ${ }^{4 f}$
}

${ }^{1}$ P. O. Box 7, Miki-cho post office, Ikenobe 3011-2, Kagawa-ken, 761-0799, Japan

${ }^{2}$ UTP University of Science and Technology in Bydgoszcz, Department of Ornamental Plants and Vegetable Crops - Laboratory of Biotechnology, Bernardyńska St. 6, PL-85-029 Bydgoszcz, Poland

${ }^{3}$ Key Laboratory of Plant Resources Conservation and Sustainable Utilization, South China Botanical Garden, the Chinese Academy of Sciences, Guangzhou, 510650, China

${ }^{4}$ Department of Plant Breeding. CEBAS-CSIC, PO Box 164, 30100 Espinardo, Murcia, Spain

Co-corresponding authors, E-mail: ajaimetex@yahoo.com; bdkulus@gmail.com; ‘xhzhang@scib.ac.cn; ${ }^{\mathrm{d}}$ zengsongjun@scib.ac.cn; emagh@scib.ac.cn; ${ }^{\mathrm{f}}$ piqueras@cebas.csic.es

\begin{abstract}
The choice of explant and its preparation are most likely one of the most important biotic factors that determine the success of a tissue culture protocol when the explant is derived from ex vitro organs. This review assesses the disinfection protocols available for saffron (Crocus sativus L.; Iridaceae) explants in an attempt to ascertain the most suitable set of parameters that could ensure successful tissue culture in subsequent treatments. From a methodological perspective, two explant types are most commonly adopted in saffron biotechnology, namely the use of fresh field-grown shoots, or dormant corms. The latter is more recommended to minimize contamination and to allow the use of more aggressive disinfection treatments.
\end{abstract}

Key words: corms, Crocus sativus, hydrogen peroxide, mercury II chloride, saffron, sodium hypochlorite, sterile distilled water, tissue culture.

Abbreviations: 2,4-D, 2,4-dichlorophenoxyacetic acid; $\mathrm{AgNO}_{3}$, silver nitrate; $\mathrm{BA}$, 6-benzyladenine; $\mathrm{Ca}(\mathrm{ClO})_{2}$, calcium chloride; ELISA, enzyme-linked immunosorbent assay; $\mathrm{GA}_{3}$, gibberellic acid; $\mathrm{H}_{2} \mathrm{O}_{2}$, hydrogen peroxide; $\mathrm{HgCl}_{2}$, mercury II chloride; HWT, hot water treatment; IAA, indole-3-acetic acid; KIN, kinetin; NAA, $\alpha$-naphthaleneacetic acid; $\mathrm{NaOCl}$, sodium hypochlorite; PCR, polymerase chain reaction; $\mathrm{PPM}^{\mathrm{TM}}$, plant preservative mixture ${ }^{\mathrm{TM}}$; SDW, sterile distilled water.

\section{Brief historical and cultural background}

Saffron (Crocus sativus L.) stigmas are likely to be the most expensive spice on earth given the fine-scale processing required to harvest the stigmas and the tiny amount of crocin, safranin and picrocrocin that can be found therein (Melnyk et al. 2010). The agronomic and biotechnological aspects of saffron and its tissue culture have been recently reviewed (Ahrazem et al. 2015; Gantait, Vahedi 2015) and thus only a brief introductory overview is provided here. The induction of embryogenic callus (see choice of callus and notes in Teixeira da Silva 2012b) from non-embryogenic callus was first reported by George et al. (1992) in which the explant used was the meristematic region of corms. In that study, the non-embryogenic callus that developed on medium with 2,4-dichlorophenoxyacetic acid (2,4-D) was transferred to medium containing indole-3-acetic acid (IAA), kinetin (KIN) and ascorbic acid, resulting in the development of somatic embryos. This was followed by the induction of embryogenic callus from bulblet explants in the presence of 6-benzyladenine (BA; see choice of BA and notes in Teixeira da Silva 2012a) and a-naphthaleneacetic acid (NAA) (Ahuja et al. 1994). Saffron embryogenic callus has a generally nodular appearance and takes about 6 weeks to form from corm tissue cultures (Blazquez et al. 2009). At the nodular stage, callus contains proembryonic structures or proglobular embryos that develop into globular embryos after 3 weeks in culture, into monopolar embryos (containing a meristem and cotyledon) after 7 weeks in culture and into bipolar embryos (consisting of an apical meristem with a cotyledon at one end and a minicorm at the opposite end) after 10 weeks in culture (Blazquez et al. 2009). Somatic embryogenesis in saffron is not very efficient and plantlet conversion from somatic embryos is low. These problems must be resolved before somatic embryogenesis can become a viable method for the mass propagation of saffron. Direct shoot regeneration without an intervening callus phase is an alternative to somatic embryogenesis and has the advantage of greater genetic uniformity compared to an indirect organogenic route from callus cultures or somatic embryos, and may take less time to generate direct shoots than callus (Blazquez et al. 
2009). In saffron, shoots have been generated directly from apical and lateral buds, small corms and ovaries (Plessner et al. 1990; Bhagyalakshami 1999; Blazquez et al. 2004a; Sharma et al. 2008; Diaz-Vivancos et al. 2011).

Micropropagation through direct organogenesis is the best technique available so far to generate a large number of genetically uniform clones. Direct shoot induction followed by microcorm formation holds promise for commercialization especially if genetically improved saffron corms (Agayev et al. 2009) are to be multiplied in a short amount of time. There are three concerns that need to be addressed to make this technology viable for saffron micropropagation: (i) effective establishment of an in vitro regeneration system; (ii) sustained multiplication of shoots from tissue culture-derived explants; (iii) field evaluation of microcorms derived from in vitro culture. As a first step, the disinfection of the explant is essential for the successful establishment of an in vitro culture, as has been elaborated in detail for Anthurium (Teixeira da Silva et al. 2015) and Dendrobium (Teixeira da Silva et al. 2016). Even though there are a substantial number of studies on saffron in vitro regeneration, the effect of disinfection on explant contamination and regeneration ability is rarely described in detail. This review looks at some theoretical aspects related to tissue disinfection in preparation for plant tissue culture, and then examines how this has been achieved in saffron to achieve a successful culture.

\section{Theory of disinfection for the establishment of plant tissue cultures}

\section{Importance of and problems related to the disinfection of underground organs}

Even though micropropagation allows for the production of numerous plants of high quality in a relatively short time, the greatest problem in this technique is contamination (Altan et al. 2010). A great variety of microrganisms (filamentous fungi, yeasts, bacteria), micro-arthropods (mites, thrips and their vectors), as well as viruses and viroids have been identified as contaminants in plant tissue cultures (Altan et al. 2010). Therefore, the asepsis of both tissues and other materials is one of the main conditions that needs to be met when establishing and maintaining plant in vitro cultures. Sterilization of equipment is not a problem in a modern laboratory that uses novel microwave-based autoclaves or pulsed-light systems that allow for the rapid (a few-minutes-long) and efficient disinfection of tools and media. The disinfection of biological material, however, is much more difficult and requires greater consideration. In plants, in theory, only the shoot apical meristem is free from any endophytes and viruses (Nesi et al. 2009). This is because apical meristems are an actively diving group of cells without a well-established vascular system but their plasmodesmata are too small to allow the cell-to-cell movement of endophytes; in addition, virus replication (i.e., the viral inactivating system) cannot cope with rapid meristem cell division, and a low water concentration and a high osmotic pressure, or high auxin levels might also limit endophytes (Elmi, West 1995; Everett 2006; Alam et al. 2013). Other tissues, however, host various microorganisms and require proper treatment prior to tissue culture initiation. Some organs are easier to disinfect than others (for example, seeds, due to the presence of their protective testa, which allows for longer or more intense treatments) or are naturally less contaminated - such as the generative organs covered by flower petals - while others, especially those that are located closer to the soil, are more heavily colonized by microorganisms. The disinfection of initial explants is a major problem in the micropropagation of geophytes (Bach, Sochacki 2013), which include important and highly profitable ornamental, cosmetic and medicinal species useful also in food production. Tulipa L., Lilium L., Narcissus L., Gladiolus L., Iris L. and Hyacinthus L. lead the cut flower sector worldwide (Çı̆̆g, Basdogan 2015). In such plants, underground organs such as modified stems, including the corms of Crocus L. spp., stem tubers of Zantedeschia Spreng. spp., the rhizomes of Iris, the pseudobulbs of orchids or the caudex of Adenium Roem. \& Schult., are the most effective or even the sole source of axillarybuds (Podwyszyńska 2012). The latter are considered to be valuable explants due to their high multiplication rate and genetic stability (Ngezayaho, Liu 2014). Rhizomes also have a greater direct regeneration potential compared to other explants that are easier to obtain, such as leaves (Ma, Gang 2006). In Lilium, Narcissus and Tulipa, the modified leaf blades born in bulbs (i.e., an underground stem with fleshy, scale-like leaf blades surrounding the apical bud) are the most important source of material for micropropagation since even though they do not contain meristematic tissue, they are able to regenerate adventitious true-to-type bulbs (Jerzy, Krzymińska 2006; Yadav et al. 2013). The level of contamination in corms and other underground organs can reach as high as 95 to $100 \%$ (Yasmin et al. 2013). Marinescu et al. (2013) compared the disinfection efficiency of various Iris aphylla L. explant types. As for rhizomes, the percent of contamination was reported to be $86 \%$, but only $20 \%$ for leaf explants. However, even though a review on the micropropagation of geophytes was published (Ascough et al. 2009), it did not - surprisingly - focus on any aspect related to the elimination of contamination. Therefore, studies on the disinfection of underground tissues and organs, as for saffron, are extremely important.

\section{Factors affecting disinfection efficiency}

There are numerous factors that can influence the efficiency of disinfection, including the conditions of cultivation and physiological state of the stock plant, the size, age and type of the explant, the type of disinfectant and its concentration, time and temperature of exposure (Teixeira da Silva et al. 2015). Finally these factors will not only affect the asepsis of 
the explant, but also its survival and regeneration potential, which are also prerequisites for an efficient transformation system and other applications of in vitro cultures. The rate of Zingiber officinale Rosc rhizome bud sprouting and differentiation increased from 4 to $50 \%$ when compared to other methods after two treatments $\left(50{ }^{\circ} \mathrm{C}\right.$ water and exposure to plant preservative mixture - PPMTM) were introduced into the disinfection procedure (Ma, Gang 2006). Langens et al. (1997) observed that hot water $\left(40^{\circ} \mathrm{C}\right)$ decreased contamination of Lilium explants, but water at 45 ${ }^{\circ} \mathrm{C}$ decreased their regeneration capacity.

Mother plants, which are the source or donors of explants, should be grown under protected conditions such as a glasshouse, or growth chambers, to minimize the population of epiphytes and pathogens (Leifert, Waites 1994, cited by Reed, Tanprasert 1995). Underground organs can be pre-incubated in perforated plastic bags containing a mixture of loose, moist soil. In Lilium philippinensis Baker, however, this resulted in a low level of aseptic culture (11 to $33 \%$ ), probably due to high moisture, which is a vehicle for the spread of bacteria (Zamora, Gruezo 1999). Reducing relative humidity during the pregrowth period can improve the outcome of infection. Seabrook and Farrell (1993) found that irrigating donor plants with filtered water, rather than city water, decreased bacterial contamination. They observed that watering greenhousegrown Solanum tuberosum L. stock plants with filtered city water decreased contamination of explant cultures by 30 to $50 \%$. Installing an ultraviolet light water-disinfecting equipment at the glasshouse inlet point can successfully reduce contamination (Seabrook, Farrell 1993).

Various types of disinfectants can be used, including chemotherapeutics (fungicides, antibiotics) hydrogen peroxide $\left(\mathrm{H}_{2} \mathrm{O}_{2}\right)$, bromine water, formaldehyde $\left(\mathrm{CH}_{2} \mathrm{O}\right)$, silver nitrate $\left(\mathrm{AgNO}_{3}\right)$, mercury II chloride $\left(\mathrm{HgCl}_{2}\right)$, sodium hypochlorite $(\mathrm{NaOCl})$ or calcium hypochlorite $\left(\mathrm{Ca}(\mathrm{ClO})_{2}\right)$. Chlorine dioxide $\left(\mathrm{ClO}_{2}\right)$, which was shown to be effective for gerbera, has not yet been tested in geophytes (Cardoso, Teixeira da Silva 2012). For bulbs, corms and rhizomes, $\mathrm{HgCl}_{2}$ (mainly) and/or $\mathrm{NaOCl}$ are the most commonly utilized (e.g., in Muscari species; Teixeira da Silva, Dobránszki 2016). $\mathrm{HgCl}_{2}$ is generally believed to be a stronger disinfectant than $\mathrm{NaOCl}$ (Marinescu et al. 2013). Unfortunately, heavy metals such as mercury are known for their immunotoxic and neurotoxic properties and are environmental pollutants (Marinescu et al. 2013). Therefore, it is recommended to use disinfection methods without $\mathrm{HgCl}_{2}$ (Yildiz 2012). Hypochlorites have been known for at least two centuries, but the main problem with their application is their instability and sensitivity to light (Connell 2006). $\mathrm{Ca}(\mathrm{OCl})_{2}$ is very effective, more stable than $\mathrm{NaOCl}$, but is poorly soluble in water (Boyette et al. 1993). Chloramine, used with tulips (Podwyszyńska, Marasek 2003), is less efficient but much more persistent (WHO 2000). $\mathrm{AgNO}_{3}$, sometimes applied to extend the vase life of ornamental plants, including geophytes (Doğan et al. 2013), can also be useful in disinfection (Yildiz 2012), since its exogenous application may increase the in vitro multiplication rate and induced floral initiation and development in shoot cultures, as was observed with Cichorium intybus L. (Bais et al. 2000). Due to the instability of $\mathrm{AgNO}_{3}$ in the presence of chlorides and other compounds in tap water or in soil-clinging organs, its application alone has limited use (Newton et al. 1933). However, when 0.05\% $\mathrm{AgNO}_{3}$ was combined with (0.15\%) potassium cyanide (KCN; 1:3 w/w), effective results with plant tissue culture were obtained (Newton et al. 1933). Silver, gold and copper nanocolloids also have antibacterial, antifungal and antiviral activities even at a low concentration and a short period of disinfection (5 to $10 \mathrm{mg} \mathrm{L}^{-1} 5$ to $10 \mathrm{~min}$ ) (Tymoszuk 2014). In addition they do not require additional washing of the explants with sterile distilled water (SDW) and cause no damage to tissue (Tymoszuk 2015). Even though these novel disinfectants may increase in popularity, their influence on genetic stability of biological material is still unknown and they have not yet been used with geophytes. It is also possible to add $\mathrm{H}_{2} \mathrm{O}_{2}$ as a chemical sterilizer into the culture medium (even without autoclaving) or to use it for washing explants (Curvetto et al. 2006). This is a nonphytotoxic solution due to the activity of plant peroxidases and catalases that act against $\mathrm{H}_{2} \mathrm{O}_{2}$ by transforming it into water and oxygen (Arora et al. 2002). This also provides a protection mechanism to preserve tissues from the harmful effects of peroxides produced by their own metabolism (Curvetto et al. 2006). An increase in $\mathrm{H}_{2} \mathrm{O}_{2}$ concentration from 0.005 to $0.020 \%$ reduced the contamination level of Lilium longiflorum 'Snow Queen' bulb scales from 52.5 to $40 \%$ after 18 weeks of culture (Curvetto et al. 2006). By increasing the $\mathrm{H}_{2} \mathrm{O}_{2}$ level in the culture medium, the number of explants with bulblets improved. Fungicides (e.g. $0.01 \%$ carbendizime and $0.1 \%$ mancozeb) and/or bacteriocides (e.g. $0.25 \%$ chloramphenicol) can also be applied prior to proper disinfection, as was done with Chlorophytum borivilliens Santapau \& R.R. Fern tuberous roots (Sharan et al. 2010).

The concentration of the disinfection agent (0.1 to 6\%) and period of exposure (typically ranging from between one minute and one hour) has to be optimized individually depending on the biological material. Obviously longer treatment with more concentrated disinfectants provides better asepsis. An increase in $\mathrm{NaOCl}$ concentration from 2 to $4 \%$ (30 $\mathrm{min}$ ) resulted in a $13.4 \%$ greater share of pure cultures of Allium aflatunense B. Fedtsch. 'Purple Sensation' and $20.0 \%$ of Allium karataviense Regel 'Ivory Queen' (Kozak, Stelmaszczuk, 2013). Prolonged application of $1: 500$ carbendazim solution and $2 \% \mathrm{NaOCl}$ (up to $30 \mathrm{~min}$ ) provided more clean Lilium 'Eyeliner' bulblet cultures in comparison to $10 \mathrm{~min}$ (Liu et al. 2012). One should keep in mind though that the viability of tissues is negatively affected by disinfectants at high concentrations 
(especially with increasing application period) resulting in the dehydration and yellowing of the explants (Pandey et al. 2009). Prolonging the treatment of Lilium bulb scales with $0.1 \% \mathrm{HgCl}_{2}$ in combination with $2 \%$ Bavistin from 2.5 to $10 \mathrm{~min}$ increased the disinfection efficiency from 29.3 to $96.0 \%$ (evaluated after one week), but the survival of biological material after 4 weeks decreased by $4 \%$ after 2.5 min disinfection and by more than $14 \%$ after 10-min treatment (Pandey et al. 2009). This indicates that contamination and survival levels of disinfected explants should not be evaluated at the same time; the issue of timing of sampling can strongly influence the reported results in plant tissue culture (Teixeira da Silva, Dobránszki 2013). Damage to explants during disinfection may have the opposite effect and lead to the spread of endogenous microorganisms, while longer disinfection with $\mathrm{NaOCl}$ may stimulate the subsequent regeneration potential of explants, probably as a response to prolonged stress, as observed with Kalanchoe tubiflora (Harvey) Hamet (Kulus 2014). Liu et al. (2012) reported that a 15 -min treatment with $2 \% \mathrm{NaOCl}$ induced over $10 \%$ greater bulblet formation in Lilium 'Eyelier' scales than a 10-min treatment. Besides the type, concentration and application period, temperature of the disinfectant is also important. Temperatures exceeding $10^{\circ} \mathrm{C}$ increase the disinfection activity of $\mathrm{NaOCl}$, which penetrates more easily into tissues (Yildiz 2012). However, heating $\mathrm{NaOCl}$ solutions may cause unpredictable changes to the concentration of available $\mathrm{Cl}^{-}$, depending upon the conditions (Frais et al., 2001). Also Altan et al. (2010) obtained a greater share (16.6\%) of fungi-infected Lilium candidium L. scale bulbs cultured in MS medium and supplemented with $0.1 \mathrm{mg} \mathrm{L}^{-1} \mathrm{NAA}+0.01 \mathrm{mg} \mathrm{L}^{-1} \mathrm{BA}$ in the dark relative to a $16-\mathrm{h}$ photoperiod $(10.4 \%)$.

\section{Disinfection procedures}

A proper disinfection procedure should preferably be cheap, efficient in terms of surface and endogenous microorganism elimination, simple enough to be performed even by an unexperienced tissue culture staff, but should also be friendly to the environment (Purohit et al. 2011). The surface disinfection of underground organs is usually carried out in four steps. (i) First, tissues are gently scrubbed under running tap water for about $10 \mathrm{~min}$ to a few hours to remove microorganisms ubiquitously covering them. The protective layer surrounding the shoot apical meristem, i.e., the tunics in saffron, can also be removed gently from the corms. Next, after optional scarification, the tissues are rinsed in running water with a drop of detergent (e.g. 0.5\% Extran) and a surfactant (Tween-20) for approx. $15 \mathrm{~min}$ (with agitation) in order to remove the lipid layer from the plant material. Detergents and other surfactants facilitate mixing of dirt with water, alter the $\mathrm{pH}$ of the organ surface, which results in breaking of hydrogen bonds via which dirt is bound to the tissue surface or leads to decomposition of the material forming the dirt through oxidation. Moreover, they reduce the water hardiness, which allows for better wetting of the plant surface and easier dissolution of ionic compounds and by forming foam they increase the contact surface with dirt and grease (Schmiedel, von Rybinski 2006). (ii) Tissues are then pretreated with 70 to $96 \%$ ethanol for a few seconds to a few minutes (in order to remove air bubbles and provide better accessibility of the tissue to the disinfectant), a fungicide (dry or liquid) and/or a bactericide, sulfuric acid (1 to $3 \mathrm{~min}$ ), or $\mathrm{PPM}^{\mathrm{TM}}$, a biocide. (iii) Explants are then transferred to a laminar air-flow chamber and treated with an appropriate disinfectant, usually a commercial bleach. (iv) Lastly, three to five rinses in sterile (double) distilled water (SDW) are applied. Sometimes explants are treated with hot water $\left(40\right.$ to $50^{\circ} \mathrm{C}$ for 1 to $4 \mathrm{~h}$ ) followed by optional overnight drying before sterilizing them with commercial bleach. Applying a two-step procedure may also be beneficial as was observed with Allium aflatunense 'Purple Sensation' and Allium karataviense 'Ivory Queen' bulbs. When a one-step disinfection procedure was applied ( $4 \% \mathrm{NaOCl}$ for $30 \mathrm{~min}$ ), $26.7 \%$ pure cultures were obtained, but after applying a two-step protocol $(2 \% \mathrm{NaOCl}$ for 30 min followed by $1 \% \mathrm{NaOCl}$ for $15 \mathrm{~min}$ ) the success rate increased to 66.6 to $80.0 \%$.

Winarto and Teixeira da Silva (2012a) observed an interaction between the disinfection method and regeneration medium on the percentage contamination, total browning and regeneration efficiency of Rumohra adiantiformis (G. Forst.) Ching rhizome cultures proving a strong correlation between those parameters. These authors also underlined the significance of the area of exposure to the sterilant and its effect on explant survival and level of disinfection. The sliced shoot tips area of rhizomesinoculated on a semi-solid regeneration medium were nearly $100 \%$ contaminated. Furthermore, it was observed that slicing the rhizomes with a tissue culture blade led to browning of the explants within $72 \mathrm{~h}$ from culture initiation and in the end caused explant necrosis. The highest share of clean cultures (50\%), as well as, highest percentage of rhizome regeneration, was achieved after inoculating full rhizomes on a simple paper bridge containing liquid regeneration medium. Only when disinfection procedures are optimized (Winarto, Teixeira da Silva 2012a) can a successful in vitro regeneration protocol be established (Winarto, Teixeira da Silva 2012b). Better regeneration potential of the explants can be achieved after cutting the underground organs (as a result of mechanical stress), however, after their disinfection (not prior to it) (Kanchanapoom et al. 2011).

\section{Elimination of endophytes}

Surface contaminants (epiphytes) are relatively easy to eliminate. Endogenous contamination (mostly bacteria, but also fungi) are a much more complicated issue, and may require antibiotic therapy (Reed, Tanprasert 1995). The antibiotics used should be stable, soluble, unaffected 
by $\mathrm{pH}$ or medium components, broadly active and cheap. Furthermore, they should have bactericidal (not only bacteriostatic) activity and not phytotoxic (Falkiner 1990). The most popular are gentamicin, rifampicin and streptomycin (they act on the prokaryotic $30 \mathrm{~S}$ or $50 \mathrm{~S}$ ribosome subunits) (Falkiner 1988). Antibiotics, however, often have a narrow target spectrum for bacteria, thus combinatorial use of antibiotics should be used in order to obtain a synergistic effect, i.e., control of microorganisms and reduction of plant damage (Altan et al. 2010). Zephyranthes grandiflora Lindl. bulb explants were treated with $0.2 \%$ Bavistin and $0.1 \%$ Pantomycin (streptomycin sulfate and tetracyclin tetrachloride) for 2, 3, 4 or $5 \mathrm{~h}$ under continuous shaking on a magnetic stirrer, prior to final disinfection with $0.1 \% \mathrm{HgCl}_{2}$ for $30 \mathrm{~s}$. It was observed that $4 \mathrm{~h}$ pretreatment resulted in the highest share (67\%) of pure living cultures after 30 days (Gangopadhyay et al. 2010). The antimicrobial effect of an antibiotic can be improved by increasing the $\mathrm{pH}$ in the culture medium to a more neutral level (approx. 7.0) (Falkiner 1988; Falagas et al. 1997).

Epiphytes and endophytes can be removed in two different stages. For Lilium candidum bulb scales, the most effective treatment against fungal contamination (over $95 \%$ of clean cultures) and to eliminate endophytes was achieved after surface disinfection with $96 \%$ ethanol ( $2 \mathrm{~min}$ ), then $2.25 \% \mathrm{NaOCl}$ with one drop of $0.1 \%$ Tween 80 (20 min) and four rinses in SDW while elimination of epiphytes was followed by treatment with Benomyl $\left(100 \mathrm{mg} \mathrm{L}^{-1}\right)+$ Nystatin (100 $\mathrm{mg} \mathrm{L}^{-1}$ ) for $30 \mathrm{~min}$ (Altan et al. 2010).

The immersion of underground Narcissus bulbs in a liquid solution of disinfectant (silver nitrate-potassium cyanide solutions) in vacuo may also be successful in eliminating endophytes by reducing infection from 26.8 to 1\% (Newton et al. 1933).

Endophytes (as well as epiphytes) can be eliminated by the use of hot-water treatment (HWT). Another advantage is the lack of chemical residues required. The technique was first developed in the $19^{\text {th }}$ century in Denmark and has, ever since, been used on a large scale with bulbs, tubers and seeds (Langens-Gerrits et al. 1997). HWT reduced initial contamination in Narcissus and Lilium bulbs from 40-60 to $5 \%$ but the temperature used is species-dependent since various pathogens have different heat sensitivities, which also depend on the host plant. Thus, for Narcissus, $54{ }^{\circ} \mathrm{C}$ for $1 \mathrm{~h}$ was optimal, but for Lilium explants, regeneration decreased after HWT at $45^{\circ} \mathrm{C}$ for $1 \mathrm{~h}$ (Langens-Gerrits et al. 1997).

\section{Elimination of viruses}

Microorganisms are not the only problem while establishing a micropropagation protocol. Bacteria and fungi can be removed during the initiation of in vitro cultures from standard disinfection of organs, but viruses [which are a serious threat with vegetatively propagated geophytes (Nesi et al. 2009), decreasing plant growth vigour] cannot. The detection of viral agents in micropropagated geophytes can be achieved by enzyme-linked immunosorbent assay (ELISA) or by more sensitive polymerase chain reaction (PCR) techniques (Dorrigiv et al. 2013; Nesi et al. 2013). Viruses can be eliminated by heat treatments (thermotherapy; e.g. 30 to 40 days at $35^{\circ} \mathrm{C}$ ) of in vivo- or in vitro-cultured plants and bulbs/bulblets and/or meristem isolation (Nesi et al. 2009).

\section{Low-cost disinfection}

Initiation of axenic cultures requires expensive equipment such as autoclaves and laminar air-flow hoods that are not affordable for hobbyists or even small producers. This limitation can be overcome by the use of easily-available substitute materials to disinfect cultures, either using fluent vapour or vapour under pressure which might be possible with a pressure cooker. This possibility allowed Curvetto et al. (2006) to obtain $60 \%$ clean cultures $(80 \%$ in the 'traditional', i.e. autoclaved method) from Lilium longiflorum 'Snow Queen' bulb scales. In addition, greater bulblet biomass was achieved and these bulblets had a higher relative growth ratio than bulblets derived from the traditional disinfection method (Curvetto et al. 2006). (Re) distilled water can be substituted by boiled tap water for media preparation. The latter costs only one third of the former, while a $\mathrm{pH}$ value of 6.0 to 6.5 is suitable for most ornamentals (Liu, Liu 2010).

Another possibility is the use of carbohydrate-free medium, which has been successfully used with numerous ornamental plant species, such as: Cymbidium grandiflorum Griff. and Zantedeschia aethiopica (L.) Spreng. (Liu, Liu 2010). In such media the contamination rate is low and there are more new leaves than when cultured in sugarcontaining medium. Photoautotrophic micropropagation significantly increased the chrysanthemum shoot mass relative to control plants, even when the density of plants was doubled (Teixeira da Silva 2014). Furthermore, such plantlets are easier to acclimatize since they are autotrophic, unlike the heterotrophic plantlets derived from sugar-containing media. Furthermore, bacteriostatic agents extracted from plants can be used to achieve asepsis by adding them directly to medium instead of autoclaving (Liu, Liu 2010). By applying phytobiotics (i.e., plant antimicrobial agents in which the combination of numerous compounds extracted from plants can kill endophytes in plants and that results in little harm to the cultured plant) instead of autoclaved medium, the contamination rate could be sustained at an acceptable level under 10\% (Cui et al. 2004).

While developing a disinfection protocol, a researcher should remember that different genotypes may display variable sensitivity to sterilizing agents and sterilization period. Therefore, choosing different disinfection methods for different cultivars is necessary, as observed with lily bulbs (Lu et al. 2005), although with Allium aflatunense 


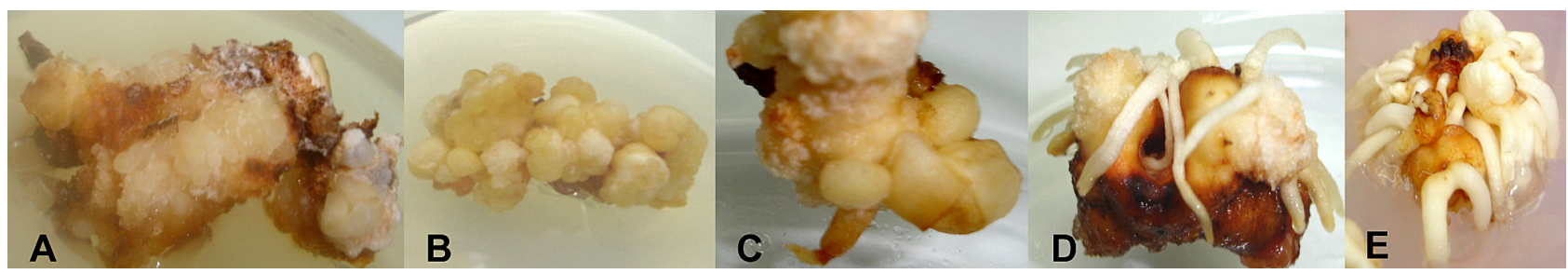

Fig. 1. In vitro response of corm slices of Crocus sativus L. formed after surface disinfection described in Table 1. (A) Callus formation on corm slices after 8 weeks. (B) Multiple cormlet production after 12 weeks. (C) Cormlet size (less notable) and callus formation after 12 weeks. (D) Cormlet (notable size) accompanied with multiple root regeneration and callus formation after 12 weeks. (E) Multiple root formation and increase in cormlet size. Figure reproduced from Quadri et al. (2010), with kind permission from Global Science Books (www.globalsciencebooks.info).

'Purple Sensation' and Allium karataviense 'Ivory Queen' bulbs the same procedure (out of five), i.e. when $\mathrm{NaOCl}$ containing $2.0 \%$ of $\mathrm{Cl}^{-}$for $30 \mathrm{~min}$ and $1.0 \% \mathrm{Cl}^{-}$for $15 \mathrm{~min}$, was used for sterilization, provided the best culture purity - 66.6 and 80.0\%, respectively (Kozak, Stelmaszczuk 2013).

\section{Disinfection of saffron tissue cultures}

Saffron in vitro tissue cultures have been initiated from several organs (Table 1): leaves, shoots, corms (Fig. 1, 2), whole flower buds or parts of the inflorescence, including the stigma, style, ovary, anthers and petals. The disinfection protocol described for most studies, however, was rarely followed by any indication of the level of infection or explant mortality after the disinfection procedure. There are also several in vitro culture studies that appeared to have used corms or other tissues from field or greenhouse-grown plants for culture initiation, but which did not describe the disinfection procedure - those studies have not been cited in this review. Other studies, like Raja et al. (2007), describe surface disinfection loosely and imperfectly, not allowing for the procedure to be replicated: "healthy leaves... were sterilized after treating them with sodium hypochlorite for 8-10 minutes." Basing their experiment on earlier knowledge of tulip bulb forcing after cold storage, one important study of saffron determined that low temperature storage of corms ( 1 to $3{ }^{\circ} \mathrm{C}$ for 9 months) provided tissue that was not infected in vitro [i.e., $0 \%$ vs 50 to $100 \%$ contamination in field-grown corms (control)], and that resulted in greater organogenesis (i.e., a greater proportion of organ-regenerating explants) as a direct result of lower contamination, but also as a direct finescale tuning of medium conditions such as plant growth regulators (Renau-Morata et al. 2013).

Surprisingly, only a few studies examined the disinfection procedure in detail. Karaoğlu et al.(2007) tested seven disinfection procedures and made some important, but incomplete, observations. They noted that a one year quarantine period (details not provided) was insufficient to eliminate endogenous contaminants and that any treatment with high temperature or sulphuric acid was damaging to explants (floral and corm segments) and did not eliminate latent endogenous contaminants that reappeared after 3 to 5 weeks in culture. The precise nature of these contaminants was not described, i.e., bacterial fungal or viral, and the authors noted that only a single treatment could eliminate contaminants, but only resulted in the formation of a

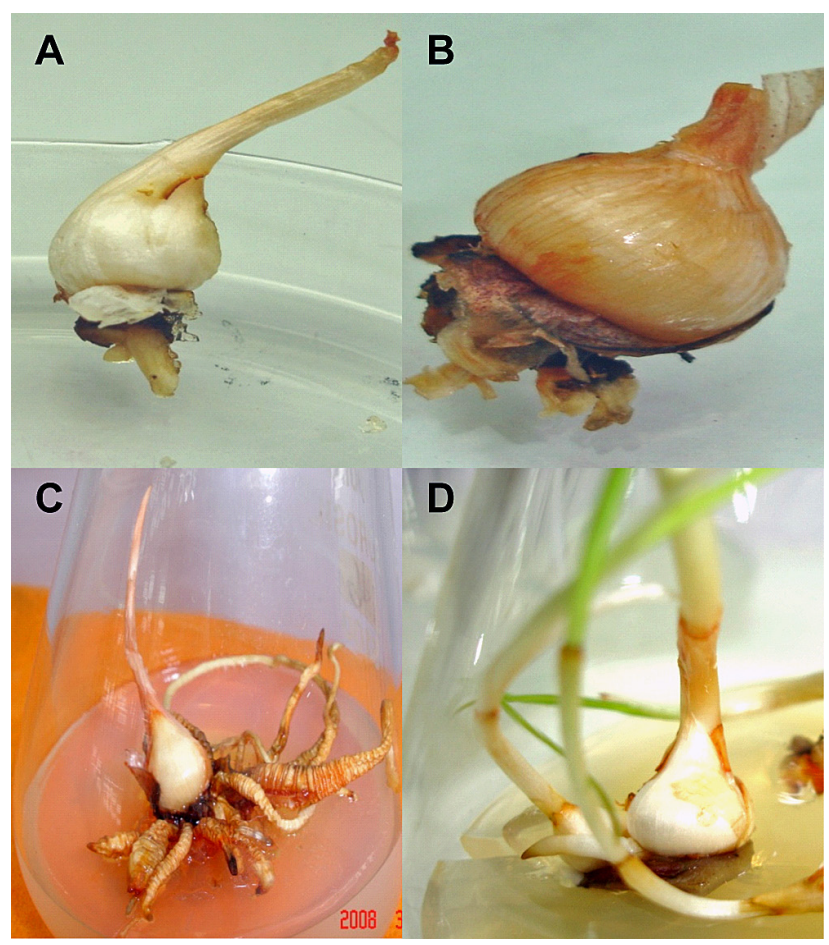

Fig. 2. In vitro response of active vegetative buds of Crocus sativus L. after the surface disinfection of corms using the following procedure: wash in running tap water with $0.5 \%$ Cedepol, a detergent, and a few drops of Tween-20, transfer to $70 \%$ ethanol for $1 \mathrm{~min}$ then to $0.1 \% \mathrm{HgCl}_{2}$ for 10 min completed with five rinses in sterile distilled water. (A) Increase in corm size on $2 \mu \mathrm{M}$ BA + $2 \mu \mathrm{M} \mathrm{NAA}+40$ to $60 \mathrm{~g} \mathrm{~L}^{-1}$ table sugar after 12 weeks. (B) Increase in corm size on $2 \mu \mathrm{M}$ BA $+2 \mu \mathrm{M}$ NAA $+40 \mathrm{~g} \mathrm{~L}^{-1}$ sucrose after 12 weeks. (C) Increase in corm size and multiple thick root formation on $8.8 \mu \mathrm{M} \mathrm{IBA}+40 \mathrm{~g} \mathrm{~L}^{-1}$ table sugar after 12 weeks. (D) Increase in corm size and germination on $2 \mu \mathrm{M} \mathrm{BA}+2 \mu \mathrm{M} \mathrm{NAA}+2.5 \mathrm{~g} \mathrm{~L}^{-1}$ $\mathrm{KCl}+40 \mathrm{~g} \mathrm{~L}^{-1}$ table sugar $+30 \mathrm{~g} \mathrm{~L}^{-1}$ sucrose after 12 weeks. Figure reproduced from Quadri et al. (2010), with kind permission from Global Science Books (www.globalsciencebooks.info). 
Table 1. Disinfection of ex vitro-derived tissues for saffron tissue culture (chronological listing). $\varnothing$, diameter; $\mathrm{AA}$, ascorbic acid; $\mathrm{AgNO}$, silver nitrate; d, day(s); DDW, double distilled water; DW, distilled water; $\mathrm{EtOH}$, ethyl alcohol (ethanol); $\mathrm{GA}_{3}$, gibberellic acid; $\mathrm{H}_{2} \mathrm{O}_{2}$, hydrogen peroxide; $\mathrm{HgCl}_{2}$, mercury chloride; $\mathrm{H}_{2} \mathrm{SO}_{4}$, sulphuric acid; mo, month(s); $\mathrm{NaOCl}$, sodium hypochlorite (values presented are assumed to represent the \% of active chlorine); NR, not reported in the study; PPM ${ }^{\mathrm{TM}}$, Plant Preservation Mixture (Plant Cell Technology); RTW, running tap water; SDW, sterilized (by autoclaving) distilled water; SDDW, sterilized (by autoclaving) double distilled water; SW, sterile water; TW, tap water; w, week(s). ${ }^{\star}$ Duplicate publication. ${ }^{*}$ Authors contacted for clarification, but none was provided

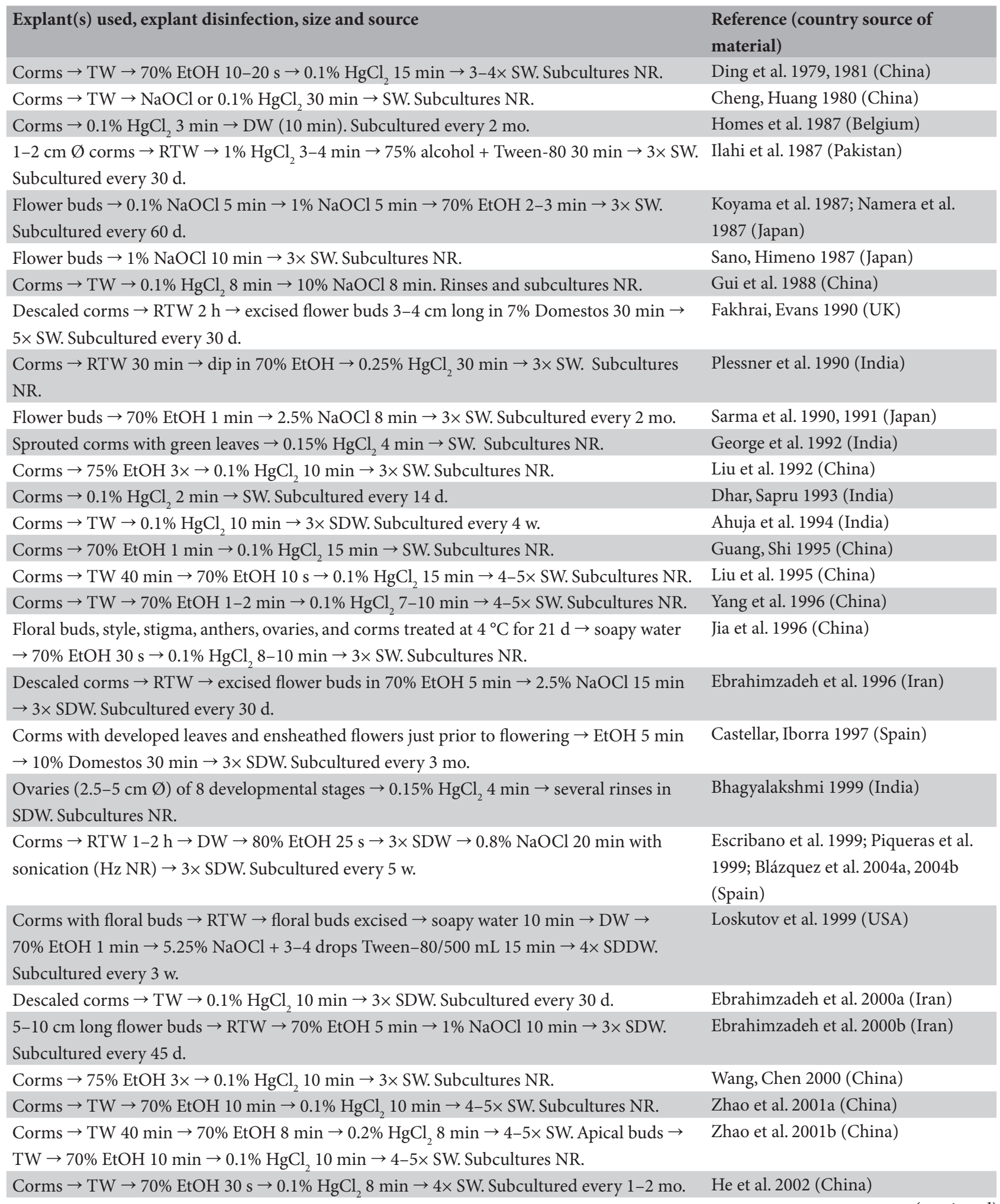


Table 1. continued $\min \rightarrow 3 \times$ SDW. Subcultures NR.

Descaled corms $\rightarrow$ one of 6 surface disinfection treatments: 1$)_{2} \mathrm{H}_{2} \mathrm{SO}_{4} 1 \mathrm{~min} \rightarrow 80 \%$ bleach

Karaoğlu et al. 2007 (Turkey)

(ACE) $20 \mathrm{~min}$; 2) $\mathrm{H}_{2} \mathrm{SO}_{4} 2.5 \mathrm{~min} \rightarrow 80 \%$ bleach (ACE) $\left.20 \mathrm{~min} ; 3\right) \mathrm{H}_{2} \mathrm{SO}_{4} 1 \mathrm{~min} \rightarrow 0.7 \%$

$\left.\mathrm{AgNO}_{3} 10 \mathrm{~min} ; 4\right) \mathrm{H}_{2} \mathrm{SO}_{4} 2.5 \mathrm{~min} \rightarrow 0.7 \% \mathrm{AgNO}_{3} 10 \mathrm{~min}$; 5) 3\% dry or liquid fungicide

(manufacturer NR); 6) 1, 2, 3, 4, 5 or 6\% PPMTM $1 \mathrm{~h}$; 7) hot water $\left(40,42.5,45\right.$ and $\left.47.5^{\circ} \mathrm{C}\right)$

(period NR) $\rightarrow 50 \%$ bleach (Axion) $20 \mathrm{~min}$. In all 7 treatments, surface disinfected corms $\rightarrow$

$5 \times$ SDW. Subcultures NR.

Descaled corms $\rightarrow$ TW $30 \mathrm{~min} \rightarrow 70 \% \mathrm{EtOH} 1 \mathrm{~min} \rightarrow 20 \% \mathrm{NaOCl} 15 \mathrm{~min} \rightarrow 3 \times \mathrm{SDW} \rightarrow$

$0.15 \% \mathrm{HgCl}_{2} 7 \mathrm{~min} \rightarrow 3 \times \mathrm{SDW}$. Subcultures NR.

Descaled corms $\rightarrow 70 \%$ EtOH $45 \mathrm{sec} \rightarrow 0.2 \% \mathrm{HgCl}_{2} 20 \mathrm{~min} \rightarrow 3 \times \mathrm{SDW} 15 \mathrm{~min}$. Subcultured

Rajabpoor et al. 2007 (Iran) every $4 \mathrm{w}$.

Corms stored at $4^{\circ} \mathrm{C} \rightarrow \mathrm{TW} \rightarrow 70 \% \mathrm{EtOH} 10 \mathrm{sec} \rightarrow 0.1 \% \mathrm{HgCl}_{2} 10 \mathrm{~min} \rightarrow 5 \times \mathrm{SDW}$.

Sharma et al. 2008 (India)

Subcultured every 1 mo.

Dormant corms (age and size NR) $\rightarrow$ RTW 2 h $\rightarrow$ dip in DW $\rightarrow$ 80\% EtOH $30 \mathrm{sec} \rightarrow 3 \times$ SDW Blázquez et al. 2009 (Spain)

$\rightarrow 0.8 \% \mathrm{NaOCl} 20 \mathrm{~min}$ with sonication $(\mathrm{Hz} \mathrm{NR}) \rightarrow 3 \times$ SDW. Explants $10 \mathrm{~mm}^{3}$ from corm

center. Subcultured every $6 \mathrm{w}$.

Flower buds $\rightarrow$ RTW 30 min $\rightarrow 0.5 \%$ benzalconium chloride 15 min $\rightarrow 70 \%$ EtOH 2 min $\rightarrow \quad$ Namin et al. 2009, 2010 (Iran)

$1 \% \mathrm{NaOCl}+$ few drops Tween-80 $20 \mathrm{~min} \rightarrow 3 \times$ SDW. Subcultured every $4 \mathrm{w}$.

Corms $\rightarrow \mathrm{TW} \rightarrow 70 \%$ EtOH $30 \mathrm{~s} \rightarrow 0.1 \% \mathrm{HgCl}_{2} 8 \mathrm{~min} \rightarrow 4-5 \times$ SW. Subcultures NR.

Wang et al. 2009 (China)

Corms $\rightarrow$ TW overnight $\rightarrow 70 \%$ EtOH 1 min $\rightarrow 0.1 \% \mathrm{HgCl}_{2} 6-15 \mathrm{~min} \rightarrow 4 \times$ SW. Subcultures Yuan et al. 2009 (China)

NR.

Ovaries from flower buds $\rightarrow \mathrm{RTW} \rightarrow 70 \% \mathrm{EtOH} 3 \mathrm{~min} \rightarrow \mathrm{NaOCl}(\% \mathrm{NR}) 10 \mathrm{~min} \rightarrow 4 \times$ SDW. Mir et al. 2010 (India)

Subcultured every $4 \mathrm{w}$.

Corms $\rightarrow$ RTW + 0.5\% Cedepol (detergent) + Tween-20 (time NR) $\rightarrow$ DDW $\rightarrow$ 70\% EtOH 1 Quadri et al. 2010 (India)

$\min \rightarrow 0.1 \% \mathrm{HgCl}_{2} 10 \mathrm{~min} \rightarrow 5 \times \mathrm{DW}$. Subcultures NR.

Flower buds $\rightarrow$ RTW $30 \mathrm{~min} \rightarrow$ dishwashing liquid $\rightarrow$ 1\% benzalconium chloride $10 \mathrm{~min} \rightarrow \quad$ Sharifi et al. 2010a, 2010b, 2012 (Iran)

$\mathrm{TW} \rightarrow 70 \% \mathrm{EtOH} 2 \mathrm{~min} \rightarrow 1 \% \mathrm{NaOCl} 15 \mathrm{~min} \rightarrow 3 \times$ SDW. Subcultured every $7 \mathrm{~d}$.

Corms $\rightarrow$ RTW $\rightarrow 70 \%$ EtOH 2 min $\rightarrow 0.1 \% \mathrm{HgCl}_{2} 5 \mathrm{~min} \rightarrow 20 \%$ bleach + Tween-20 10 min Vatankhah et al. 2010, 2014 (Iran)

$\rightarrow 3 \times$ SDW. Subcultures NR.

Descaled corms $\rightarrow$ RTW $1 \mathrm{~h} \rightarrow$ brushed with Tween-20 $\rightarrow 0.1 \%$ streptomycin sulphate $+\quad$ Devi et al. 2011, 2014 (India)

$0.1 \%$ Bavistin $30 \mathrm{~min} \rightarrow \mathrm{DW} \rightarrow 70 \% \mathrm{EtOH} 30-45 \mathrm{~s} \rightarrow 0.1 \% \mathrm{HgCl}_{2} 10-12 \mathrm{~min} \rightarrow 5-6 \times$ SDW.

Subcultures NR.

(continued) 
Table 1. continued

\begin{tabular}{|c|c|}
\hline Explant(s) used, explant disinfection, size and source & $\begin{array}{l}\text { Reference (country source of } \\
\text { material) }\end{array}$ \\
\hline $\begin{array}{l}\text { Shoots derived from sprouting corms } \rightarrow \text { RTW } 2 \mathrm{~h} \rightarrow \mathrm{DW} \rightarrow 80 \% \text { EtOH } 30 \mathrm{~s} \rightarrow 6 \times \mathrm{SDW} \rightarrow \\
0.8 \% \mathrm{NaOCl} 20 \text { min with sonication }(\mathrm{Hz} \text { NR) } \rightarrow 3 \times \text { SDW. Subcultures NR. }\end{array}$ & Diaz-Vivancos et al. 2011 (Spain) \\
\hline $\begin{array}{l}\text { Corms stored at } 4^{\circ} \mathrm{C} \text { for } 48 \mathrm{~h} \rightarrow \mathrm{TW} 0.5-1 \mathrm{~h} \rightarrow 2 \times \mathrm{SW} \rightarrow 70 \% \text { EtOH } 30 \mathrm{~s} \rightarrow 0.1 \% \mathrm{HgCl}_{2} 8 \\
\text { min } \rightarrow 4-5 \times \mathrm{SW} \text {. Subcultures NR. }\end{array}$ & Wang et al. 2011 (China) \\
\hline $\begin{array}{l}\text { Corms } \rightarrow \text { RTW }+0.5 \% \text { Extran (detergent) }+ \text { Tween- } 20(\text { time NR) } \rightarrow \text { DDW } \rightarrow 70 \% \text { EtOH } 1 \\
\text { min } \rightarrow 0.5 \% \mathrm{HgCl} 26 \mathrm{~min} \rightarrow 5 \times \text { DW. Subcultures NR. }\end{array}$ & Parray et al. 2012 (India) \\
\hline $\begin{array}{l}\text { Leaves (age / developmental stage NR) } \rightarrow \text { RTW } 20 \mathrm{~min} \rightarrow 5.25 \% \mathrm{NaOCl}+\text { Tween-80 } 10 \mathrm{~min} \\
\rightarrow 3 \times \text { DW. Subcultures NR. }\end{array}$ & Sharafzadeh 2012 (Iran) \\
\hline $\begin{array}{l}\text { Corms } \rightarrow \text { RTW } 30 \text { min } \rightarrow \text { tunics removed } \rightarrow 70 \% \text { EtOH } 30 \mathrm{sec} \rightarrow 0.15 \% \mathrm{HgCl}_{2} 20 \mathrm{~min} \rightarrow 3 \times \\
\text { DW. Subcultured every } 3 \mathrm{w} .\end{array}$ & Zeybek et al. 2012 ( Turkey) \\
\hline $\begin{array}{l}\text { Corms } \rightarrow \text { immersed in water with dishwashing liquid for } 5 \mathrm{~min} \rightarrow \mathrm{TW} 30 \mathrm{~min} \rightarrow 0.05 \% \\
\mathrm{HgCl}_{2} 30 \mathrm{~min} \rightarrow 2 \times \mathrm{SW} \rightarrow 0.02 \% \mathrm{HgCl}_{2} 2 \mathrm{~min} \rightarrow 4 \times \mathrm{SW} \text { for } 10 \mathrm{~min} \text {. Subcultures NR. }\end{array}$ & Wang, Xiao 2012 (China) \\
\hline 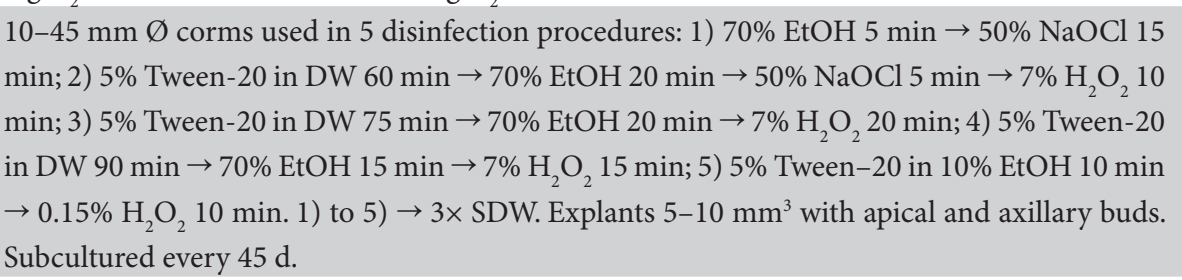 & Cavusoglu et \\
\hline $\begin{array}{l}\text { Corms } \rightarrow \mathrm{TW} \rightarrow 70 \% \text { EtOH } 2 \mathrm{~min} \rightarrow 5 \% \mathrm{NaOCl}+0.1 \% \text { Tween-20 } 10 \text { min } \rightarrow \text { corms cut into } \\
\text { segments } \rightarrow 70 \% \text { EtOH } 10 \mathrm{sec} \rightarrow 0.1 \% \mathrm{HgCl}_{2} 3 \mathrm{~min} \rightarrow 4 \times \text { SDW. Subcultures NR. }\end{array}$ & Lapadatescu et al. 2013 (Romania) \\
\hline $\begin{array}{l}\text { Corms (low temperature storage and controls) with tunics removed } \rightarrow 70 \% \text { EtOH } 30 \mathrm{sec} \rightarrow \\
3 \times \mathrm{SW} \rightarrow 0.8 \% \mathrm{NaOCl} 20 \mathrm{~min} \rightarrow \text { sonication (time and } \mathrm{Hz} \mathrm{NR}) \rightarrow 3 \times \mathrm{SDW} \text {. Subcultures NR. }\end{array}$ & Renau-Morata et al. 2013 (Spain) \\
\hline $\begin{array}{l}\text { Corms } \rightarrow 70 \% \text { EtOH } 1 \mathrm{~min} \rightarrow 35 \% \mathrm{NaOCl} 7 \mathrm{~min} \rightarrow 35 \% \text { nano-silver (precise specifications } \\
\mathrm{NR}) 10 \mathrm{~min} \rightarrow \text { several washes in SDW. Subcultures NR. }\end{array}$ & Shahabzadeh et al. 2013 (Iran) \\
\hline $\begin{array}{l}\text { Corms } \rightarrow \text { RTW } 10 \mathrm{~min} \rightarrow 0.1 \% \text { carbendizime }+0.2 \% \text { mancozeb (fungicides) + Tween-20 } 10 \\
\min \rightarrow 50 \% \mathrm{NaOCl} 10 \mathrm{~min} \rightarrow 1.6 \% \mathrm{HgCl}_{2} 5 \mathrm{~min} \rightarrow \text { SDW. Subcultures NR. }\end{array}$ & $\begin{array}{l}\text { Yasmin et al. 2013; Yasmin, Nehvi } \\
\text { 2014a, 2014b (India) }\end{array}$ \\
\hline $\begin{array}{l}\text { Apical buds from flower buds } \rightarrow \mathrm{RTW} \rightarrow 70 \% \mathrm{EtOH} 3-4 \mathrm{~min} \rightarrow 0.1 \% \mathrm{HgCl}_{2} 10 \min \rightarrow 5 \times \\
\text { SDW. Subcultured every } 4 \mathrm{w} \text {. }\end{array}$ & Mir et al. 2014 (India) \\
\hline Corms $\rightarrow$ TW $1 \mathrm{~h} \rightarrow 70 \%$ EtOH $30 \mathrm{~s} \rightarrow 0.1 \% \mathrm{HgCl}_{2} 15 \mathrm{~min} \rightarrow 4 \times$ SW. Subcultures NR. & Peng, Hu 2014 (China) \\
\hline $\begin{array}{l}\text { Corms } \rightarrow \text { RTW } 30 \mathrm{~min} \rightarrow \text { detergent } \rightarrow 1 \% \text { benzalconium chloride } 10 \mathrm{~min} \rightarrow \mathrm{TW} \rightarrow 70 \% \mathrm{EtOH} \\
4 \mathrm{~min} \rightarrow 1 \% \mathrm{NaOCl} 15 \mathrm{~min} \rightarrow 3 \times \mathrm{SDW} . \text { Subcultured every } 1 \mathrm{mo} .\end{array}$ & Vahedi et al. 2014, 2015 (Iran) \\
\hline $\begin{array}{l}\text { Corms } \rightarrow 5 \% \mathrm{NaOCl} 8 \mathrm{~min} \text { (shaking) } \rightarrow 80 \% \mathrm{EtOH} 1 \mathrm{~min} \rightarrow 37 \% \text { nanosilver }^{\star *} 17 \mathrm{~min} \\
\text { (shaking) } \rightarrow 3 \times \text { DW. Subcultured every } 1 \mathrm{mo} .\end{array}$ & Abbas, Elahe 2015 (Iran) \\
\hline Corms $\rightarrow$ RTW $\rightarrow 70 \%$ EtOH $3 \mathrm{~min} \rightarrow \mathrm{NaOCl} 10 \mathrm{~min} \rightarrow 4 \times$ SDW. Subcultured every $3 \mathrm{w}$. & Mir et al. 2015 (India) \\
\hline $\begin{array}{l}\text { Corms } \rightarrow \mathrm{TW} \rightarrow 75 \% \text { EtOH } 60 \mathrm{~s} \rightarrow 3-4 \times \mathrm{SW} \rightarrow 0.1 \% \mathrm{HgCl}_{2} 12-15 \mathrm{~min} \rightarrow 3-4 \times \mathrm{SW} \text {. Subcultures } \\
\text { NR. }\end{array}$ & Yang et al. 2015 (China) \\
\hline
\end{tabular}

limited number of viable explants (corms). Cavusoglu et al. (2013) compared five disinfection procedures and assessed the percentage explant (corm segments) contamination after 30 days, finding the percentage of contaminated cultures to be $0,17,60,83$ and $93 \%$ for methods 1 to 5 in Table 1, respectively. Yasmin et al. (2013) found that just over $30 \%$ of control cultures (i.e., corms not undergoing any surface disinfection) were uncontaminated, but that the level of contamination was reduced as the level of $\mathrm{HgCl}_{2}$ increased, peaking at $94 \%$ contaminant-free culture when $1.6 \% \mathrm{HgCl}_{2}$ was used (time period not described). In all cases, fungicides were also simultaneously applied and concentrations of $\mathrm{HgCl}_{2}$ exceeding $1.6 \%$ or high levels of sodium hypochlorite surprisingly (as the opposite would be expected) decreased the percentage of contaminantfree cultures, and also explant survival to $46.43 \%$ (Yasmin and Nehvi 2014b). Abbas and Elahe (2015) claimed to use $37 \%$ nanosilver, but what this percentage means, or its commercial source, were not indicated, nor was the final explant contamination level quantified.

Since saffron leaves are basal without a general stem, and since the growth point (shoot apical meristem) is located at the base of the leaves where they are connected to the corm, it is difficult to isolate shoot tips. In the Chinese literature, 
it was shown that the survival of shoot tips less than 0.5 $\mathrm{mm}$ in length - essential for the development of virus-free material - was low, but that disinfection of large shoot tips (>0.5 mm) was better than for shoot tips less than $0.5 \mathrm{~mm}$. The survival rate of explants increased to $85 \%$ when shoot tips longer than $1 \mathrm{~mm}$ were cultured after disinfection (Zhu et al. 2009). Chen et al. (2006) used a two-step disinfection method to obtain uncontaminated shoots from the corms of $C$. sativus. In the first step, shoots induced from callus tissue according to the method of Chen et al. (2003a) were subcultured on MS supplemented with $0.25 \mathrm{mg} \mathrm{L}^{-1}$ 2,4-D, 2 $\mathrm{mg} \mathrm{L} \mathrm{L}^{-1} \mathrm{BA}$ and $200 \mathrm{mg} \mathrm{L}^{-1}$ casein hydrolysate and cultured at $35^{\circ} \mathrm{C}$ for 25 days (10-h photoperiod). The new shoots were used to induce callus once again. Induced callus was transferred to MS containing $0.5 \mathrm{mg} \mathrm{L}^{-1} \mathrm{NAA}$ and 0.25 mg L $\mathrm{L}^{-1} \mathrm{BA}$ and cultured at $35^{\circ} \mathrm{C}$ for 40 days (continuous darkness), then shoots were induced from callus tissue on MS medium supplemented with $0.25 \mathrm{mg} \mathrm{L}^{-1} 2,4-\mathrm{D}$ and $2 \mathrm{mg} \mathrm{L}^{-1} \mathrm{BA}$. Finally, uncontaminated shoots that were generated after 50 days of culture were tested by combining ELISA and RT-PCR. Zhu et al. (2009) obtained saffron plantlets free of CMV (Cucumber mosaic virus), TuMV (Turnip mosaic virus), TRV (Tobacco rattle virus) and IMV (Iris mosaic virus) free by two methods: (i) temperature treatment combined with shoot tip culture; (ii) chemical treatment combined with shoot tip culture, after corms were disinfected with $75 \% \mathrm{EtOH}$ and $0.1 \% \mathrm{HgCl}_{2}$ for 12 min. In method 1, corms (age not indicated) with shoots were treated at $36^{\circ} \mathrm{C}$ for $12 \mathrm{~h}$ then at $18{ }^{\circ} \mathrm{C}$ for $12 \mathrm{~h}$, outer tunics were removed and 0.5 to $1.0 \mathrm{~mm}$ shoot tips were cultured, resulting in $26.7 \%$ survival. In method 2, 0.5 to 1.0 $\mathrm{mm}$ shoot tips stripped from corms 3 to $5 \mathrm{~cm}$ in diameter with leaves were added to MS medium supplemented with $5.0 \mathrm{mg} / \mathrm{L} \mathrm{BA}, 3.0 \mathrm{mg} \mathrm{L}^{-1} \mathrm{NAA}$, and 5 to $10 \mathrm{mg} \mathrm{L}^{-1}$ ribavirin. The survival rate of shoot tips ranged from 25 (when $10 \mathrm{mg}$ $\mathrm{L}^{-1}$ ribavirin was used) to $45 \%$ (when $5 \mathrm{mg} \mathrm{L}^{-1}$ ribavirin was used) (Zhu et al. 2009).

Most studies in the Chinese saffron literature have followed a fairly standard procedure for the disinfection of tissues for in vitro shoot or callus induction, broadly including a wash with tap water, surface disinfection with $70 \% \mathrm{EtOH}$, treatment with $0.1 \% \mathrm{HgCl}_{2}$ and a final rinse with sterile water (Table 1). The number of times explants were rinsed with tap water varied, although most studies did not report on the precise period while a few studies described it as 0.5 h to overnight (Liu et al. 1995; Yuan et al. 2009; Wang et al. 2011). Explant disinfection with $0.1 \% \mathrm{HgCl}_{2}$ for 8 to 15 min was a general trend, with the exception of three studies that employed $\mathrm{NaOCl}$ for 15 to $20 \mathrm{~min}$ (Chen et al. 2003a; 2003b; 2004a; 2004b). Chen et al. (2003a; 2003b; 2004a; 2004b) reported disinfection methods for different saffron explants that were not exactly the same. The disinfection procedure for shoots, leaves and flower explants involved a rinse in tap water for 1 to $2 \mathrm{~h}$, a wash with distilled water, a dip in $70 \%$ ethanol for $20 \mathrm{~s}$, treatment for $20 \mathrm{~min}$ in $1 \% \mathrm{NaOCl}$, and then five rinses with SDW. In contrast, the disinfection procedure for corms was two washes with distilled water, a dip in $70 \%$ ethanol for $30 \mathrm{~s}$, transfer to $2 \% \mathrm{NaOCl}$ for $15 \mathrm{~min}$, and then five rinses with SDW. In two studies, corms were stored at $4{ }^{\circ} \mathrm{C}$ for $48 \mathrm{~h}$ and 40 days, respectively, prior to rinsing with tap water, but the exact reason for the cold treatment was not explained (Zhang et al. 2007; Wang et al. 2011), although Zhang et al. (2007) first treated explants with 0.5 to $1.0 \mathrm{mg} \mathrm{L}^{-1}$ gibberellic acid $\left(\mathrm{GA}_{3}\right)$ prior to cold storage. In geophytes in general and specifically in saffron, a cold period of vernalization is required for the adequate induction of flowering and further development of shoots. From a physiological point of view, cold treatments can modulate endogenous levels of hormones implicated (gibberellins) in the retardation of new meristem development and sprouting (Plessner et al. 1989).

In order to achieve better results, a two-step procedure is often used in saffron tissue disinfection procedures. During the first step, entire organs are surface disinfected. At first, redundant parts (leaves and/or roots) are removed, organs are washed extensively with water containing a few drops of Teepol $(0.1 \%, \mathrm{v} / \mathrm{v})$ and sterilized by washing in 70 to $90 \%$ ethanol (5 min) and then for $30 \mathrm{~min}$ in $3-5 \%$ $\mathrm{Ca}(\mathrm{ClO}) 2$ with three or more rinses in SDW. During the second step, the outer tissues (epidermal layers) of the remaining organ are removed and the inner tissues are cut into pieces (approx. $3 \mathrm{~cm}$ thick). The fragments are washed with SDW and treated with $\mathrm{Ca}(\mathrm{ClO})_{2}$ for $30 \mathrm{~min}$, with three or more rinses in SDW (Ndong et al. 2006). It is also possible to use two sterilizing agents, sequentially (usually $\mathrm{NaOCl}$ followed by $\mathrm{HgCl}_{2}$ ). For example, the combination of systemic fungicides with bleach at 50\% $(10 \mathrm{~min})$ and a dip in $1.6 \% \mathrm{HgCl}_{2}$ for 5 min provided $94 \%$ clean viable saffron corm cultures (Yasmin et al. 2013). Sivanesan et al. (2014) was able to obtain $100 \%$ aseptic cultures of Crocus vernus (L.) Hill corms after applying 2.0\% (v/v) NaOCl for $10 \mathrm{~min}$ followed by three washes with SDW, treatment with $0.01 \%(\mathrm{w} / \mathrm{v}) \mathrm{HgCl}_{2}$ for $15 \mathrm{~min}$, while Cavusoglu et al. (2013) obtained the same results after combining $50 \% \mathrm{NaOCl}(15$ min) and $7 \% \mathrm{H}_{2} \mathrm{O}_{2}(15 \mathrm{~min})$.

It is curious to note that Zaffar et al. (2014) cultured corm directly onto tissue culture medium without describing any surface disinfection procedure, which is highly unlikely. Indeed, photographic evidence provided by these authors indicates that stigma-like structures formed in 4-month old cultures that were apparently free of contamination, although the authors did not specifically address the issue of contamination. Similarly, Chichiriccò and Grilli Caiola (1987) excised ovaries aseptically and plated them directly in vitro without describing any surface disinfection protocol or accompanying medium infection. Although Majourhat et al. (2007) claimed that less than $30 \%$ of apical and axillary shoots were contaminated in vitro, presumably less than corm tissue, the actual disinfection procedure was 
not described.

This mini-review focuses on a segment of biotechnology that is rarely discussed in detail, mainly because it pertains to negative results. However, there is great value in negative results, but whose publication and discussion are limited primarily by a negative stigma (Teixeira da Silva 2015). Thus the objective of this review was to draw upon broad tissue culture principles for the establishment of in vitro cultures and to seek evidence and results from within the saffron literature, including negative elements, which will make future efforts to establish in vitro cultures by saffron researchers easier.

\section{Insight to successful establishment of saffron tissue cultures from phytopathology}

Many pathogenic and non-pathogenic microbiota have been described for saffron. Viral infections like those caused by TuMV are known (Ahrazem et al. 2010), but from a tissue disinfection perspective, fungal infections are the most important. Species/strains of many fungal/ oomycete genera have been described and a significant proportion of them are endophytic, which might cause less efficient surface disinfection of explants used for tissue culture. Species of Fusarium are the most important pathogens, causing corm rot disease (Ahrazem et al. 2010; Husaini et al. 2010). During saffron flowering, if the crop is infected by Fusarium oxysporum f. sp. gladioli and solani, Fusarium pallidoroseum, Fusarium equiseti, Mucor sp. and Penicillium sp., then yellowing, wilting of shoots, basal stem and corm rot and major yield losses can occur (Di Primo et al. 2002; Kalha, Gupta 2009). Fusarium isolates can be characterized by pathogenicity and vegetative compatibility tests but can be eliminated from saffron corms with a simple surface-disinfection with $1 \% \mathrm{NaOCl}$ (Di Primo et al. 2002). Other genera that have been detected are Aspergillus, Beauveria, Penicillium, Phytophtora, Rhizoctonia and Uromyces (Uromyces croci is known for the colonization of saffron organs) (Ahrazem et al. 2010; Husaini et al. 2010). Pathogenic bacteria affecting saffron yield are not common. However, there are some reports showing saffron diseases of bacterial origin. Fiori et al. (2011) proved that Burkholderia gladioli and other species belonging to this genus were responsible for shoot, leaf and corm rot in saffron cultivated in Sardinia, Italy. On the other hand, Ambardar and Vakhlu (2013) detected rhizosphere bacterial communities with Bacillus, Brevibacterium and Pseudomonas promoting saffron growth, one possible reason being that most of these bacteria produced IAA.

\section{Conclusions}

At present, saffron is propagated vegetatively by using annually renewed corms. Fungal infestation of corms is a bottleneck limiting the availability of sufficient quality planting material (Yasmin et al. 2013). As for geophytes, disinfection of underground organs to establish axenic cultures is very difficult. Most epiphytic microorganisms develop during the first stage of tissue culture, but endophytic microorganisms may remain cryptic and not be detected until a more advanced culture phase (Curvetto et al. 2006). The literature pertaining to saffron and other geophytes has considerable errors, including the lack of details related to disinfection protocols or the efficiency of protocols. In the future, traditional disinfectants such as $\mathrm{NaOCl}$ or $\mathrm{HgCl}_{2}$ might be replaced with more efficient and user-friendly nanocolloids $(\mathrm{Ag}, \mathrm{Au}, \mathrm{Cu})$. Thus far developed shoots or dormant corms have been used, but to obtain a balance between eliminating infection and having tissue that is receptive in vitro, future experiments could consider employing sprouting corms for culture initiation and multiplication.

\section{Acknowledgements}

The authors thank Mafat M. Kher (Sardar Patel University) for providing some difficult-to-access literature. The authors also thank the discussion and exchange of ideas provided by Gyula Surányi and Csaba Máthé, at the Department of Botany, Faculty of Science and Technology, University of Debrecen, in Hungary. The authors declare no conflicts of interest. The authors contributed equally to all parts of the development and revisions of this review.

\section{References}

Abbas M.S., Elahe P. 2015. Evaluation of callus formation and embryogenesis in saffron (Crocus sativus L.) for flower harvesting. J. Biodiver. Environ. Sci. 6: 127-131.

Agayev Y.M., Fernandez J.A., Zarifi E. 2009. Clonal selection of saffron (Crocus sativus L.): the first optimistic experimental results. Euphytica 169: 81-99.

Ahrazem O., Rubio-Moraga Á., Castillo-López R., Mozos A.T., Gómez-Gómez L. 2010. Crocus sativus pathogens and defence responses. Funct. Plant Sci. Biotechnol. 4: 81-90.

Ahrazem O., Rubio-Moraga A., Nebauer S.G., Molina R.V., GómezGómez L. 2015. Saffron: its phytochemistry, developmental processes, and biotechnological prospects. J. Agric. Food Chem. 63: 8751-8764.

Ahuja A., Koul S., Ram G., Kaul B.L. 1994. Somatic embryogenesis and regeneration of plantlets in saffron, Crocus sativus L. Indian J. Exp. Biol. 32: 135-140.

Alam I., Sharmin S.A., Naher M.K., Alam M.J., Anisuzzaman M., Alam M.F. 2013. Elimination and detection of viruses in meristem-derived plantlets of sweetpotato as a low-cost option toward commercialization. Biotechnology 3: 153-164.

Altan F., Bürün B., Sahin N. 2010. Fungal contaminants observed during micropropagation of Lilium candidum L. and the effect of chemotherapeutic substances applied after sterilization. African J. Biotechnol. 9: 991-995.

Ambardar S., Vakhlu J. 2013. Plant growth promoting bacteria from Crocus sativus rhizosphere. World J. Microbiol. Biotechnol. 29: 2271-2279.

Arora A., Sairam R.K., Srivastava G.C. 2002. Oxidative stress and 
antioxidative system in plants. Curr. Sci. 82: 1227-1238.

Ascough D.D., Erwin J.E., van Staden J. 2009. Micropropagation of Iridaceae - a review. Plant Cell Tissue Organ Cult. 97: 1-19.

Bach A., Sochaki D. 2013. Propagation of ornamental geophytes: physiology and management systems. In: Kamenetsky R., Okubo H. (eds.) Ornamental Geophytes from Basic Science to Sustainable Production,. CRC Press, Boca Raton, pp. 261-287.

Bais H.P., Sudha G.S., Ravishankar G.A. 2000. Putrescine and silver nitrate influences shoot multiplication, in vitro flowering and endogenous titers of polyamines in Cichorium intybus L. cv. Lucknow Local. J. Plant Growth Regul. 19: 238-248.

Bhagyalakshmi N. 1999. Factors influencing direct shoot regeneration from ovary explants of saffron. Plant Cell Tissue Organ Cult. 58: 205-211.

Blázquez S., Olmos E., Hernández J.A., Fernández-García N., Fernández J.A., Piqueras A. 2009. Somatic embryogenesis in saffron (Crocus sativus L.). Histological differentiation and implication of some components of the antioxidant enzymatic system. Plant Cell Tissue Organ Cult. 97: 49-57.

Blázquez S., Olmos E., Hernández J.A., Hellín E., Fernández J.A., Piqueras A. 2004a. Somatic embryogenesis in saffron (Crocus sativus L.): morphological differentiation and the role of the antioxidant enzymatic system. Acta Hortic. 650: 261-267.

Blázquez S., Piqueras A., Serna M., Casas J.L., Fernández J.A. 2004b. Somatic embryogenesis in saffron: optimisation through temporary immersion and polyamine metabolism. Acta Hortic. 650: 269-276.

Boyette M.D., Ritchie D.F., Carballo S.J., Blankenship S.M., Snader D.C. 1993. Chlorination and postharvest control. Hort. Technol. 3: 395-400.

Cardoso J.C., Teixeira da Silva J.A. 2012. Micropropagation of gerbera in culture medium sterilized with liquid chlorine dioxide $\left(\mathrm{ClO}_{2}\right)$. In Vitro Cell. Dev. Biol. Plant 48: 362-368.

Castellar M.R., Iborra J.L. 1997. Callus induction from explants of Crocus sativus. J. Plant Biochem. Biotechnol. 6: 97-100.

Cavusoglu A., Sulusoglu M., Erkal S. 2013. Plant regeneration and corm formation of saffron (Crocus sativus L.) in vitro. Res. J. Biotechnol. 8: 128-133.

Chen W., Huang R.X. 1980. Tissue culture of Crocus sativus L. Plant Physiol. Comm. 1: 25-26.

Chen S.A., Wang X.D., Ou Y.J. 2003a. Investigation on rapidly induction of Crocus sativus callus taking corm as explant. Chin. Pharm. J. 38: 254-256. /in Chinese with an English abstract/

Chen S.A., Wang X.D., Zhao B., Yuan X.F., Wang Y.C. 2003b. Production of crocin using Crocus sativus callus by two-stage culture system. Biotechnol. Lett. 25: 1235-1238.

Chen S., Wang X., Zhao B., Wang Y. 2004. Screening of Crocus sativus L. callus lines for crocin production. Chinese Bull. Bot. 21: 455-460.

Chen S.A., Zhao B., Wang X.D., Yuan X.F., Wang Y.C. 2004. Promotion of the growth of Crocus sativus cells and the production of crocin by rare earth elements. Biotechnol. Lett. 26: $27-30$

Chen S.A., Chen W.B., Wang X.D., Zhao B., Wang Y.C. 2006. Acquisition of virus-free tissue shoots of Crocus sativus L. and detection of their viruses. Chinese High Technol. Lett. 16: 1170-1175. /in Chinese with an English abstract/

Chichiriccò G., Grilli Caiola M. 1987. In vitro development of parthenocarpic fruits of Crocus sativus L. Plant Cell Tissue Organ Cult. 11: 75-78.

Çı̆̆ A., Basdogan G. 2015. In vitro propagation techniques for some geophyte ornamental plants with high economic value. Int. J. Secondary Metab. 2: 27-49.

Connell G.F. 2006. Key operating strategies for chlorine disinfection operating systems. Water Environment Foundation, Warminster.

Cui G., Shan W.X., Qin X., Sun Z.X. 2004. The preliminary study on plant open-tissue-culture. J. Shandong Agric. Univ. 35: 529-533.

Curvetto N., Marinangeli P., Mockel G. 2006. Hydrogen peroxide in micropropagation of Lilium. A comparison with a traditional methodology. Biocell 30: 497-500.

Darvishi E., Zarghami R., Mishani C.A., Omidi M. 2006a. Effects of different hormone treatments on non-embryogenic and embryogenic callus induction and time-term enzyme treatments on number and viability of isolated protoplasts in saffron (Crocus sativus L.). Acta Hortic. 739: 279-284.

Darvishi E., Zarghami R., Mishani C.A., Omidi M., Sarkhosh A. 2006b. In vitro production of pathogen-free plantlets via meristem culture in saffron (Crocus sativus L.). Biotechnology 5: 292-295.

Devi K., Sharma M., Ahuja P.S., 2014. Direct somatic embryogenesis with high frequency plantlet regeneration and successive cormlet production in saffron (Crocus sativus L.). S. Afr. J. Bot. 93: 207-216.

Devi K., Sharma M., Singh M., Singh Ahuja P. 2011. In vitro cormlet production and growth evaluation under greenhouse conditions in saffron (Crocus sativus L.) - a commercially important crop. Eng. Life Sci. 11: 189-194.

Dhar A.K., Sapru R. 1993. Studies on saffron (Crocus sativus) in Kashmir. III. In vitro production of corm and shoot like structures. Indian J. Genet. Plant Breed. 53: 193-196.

Díaz-Vivancos P., Majourhat K., Fernández J.A., Hernández J.A., Piqueras A. 2011. Study of the antioxidant enzymatic system during shoot development from cultured intercalar meristems of saffron. Plant Growth Reg. 65: 119-126.

Ding B.Z., Bai S.H., Wu Y., Wang B.K. 1979. Preliminary report on tissue culture of corms of Crocus sativus. Acta Bot. Sin. 21: 387. /in Chinese/

Ding B.Z., Bai S.H., Wu Y., Wang B.K., Fang X.P. 1981. Induction of callus and regeneration of plantlets from corms of Crocus sativus L. Acta Bot. Sin. 23: 419-420. /in Chinese/

Di Primo P., Cappelli C., Katan T. 2002. Vegetative compatibility grouping of Fusarium oxysporum f. sp. gladioli from saffron. Eur. J. Plant Pathol. 108: 869875.

Doğan A., Yılmaz G., Erkan M., Baktır I. 2013. Effect of sucrose and silver nitrate on the vase life of Ranunculus asiaticus L. Acta Hortic. 1002: 341-348.

Dorrigiv R., Jafarpour B., Rastegar F.M. 2013. Detection of some virus pathogens of gladiolus in Iran. Int. J. Agric. Crop Sci. 5: 1653-1658.

Ebrahimzadeh H., Karamian R., Noori-Daloii M.R. 2000a. Somatic embryogenesis and regeneration of plantlet in saffron, Crocus sativus L. J. Sci. Islam. Repub. Iran 11: 169-173.

Ebrahimzadeh H., Radjabian T., Karamian R. 2000b. In vitro production of floral buds and stigma-like structures on floral organs of Crocus sativus L. Pak. J. Bot. 32: 141-150.

Ebrahimzadeh H., Karamian R., Noori-Daloii M.R. 1996. In vitro regeneration of shoot and corm from the different explants of Crocus sativus L. J. Sci. Islam. Repub. Iran 7: 57-62.

Elmi A.A., West C.P. 1995. Endophyte infection effects on stomatal conductance, osmotic adjustment and drought recovery of tall fescue. New Phytol. 131: 61-67. 
Escribano J., Piqueras A., Medina J., Rubio A., Alvarez-Orti M., Fernández J.A. 1999. Production of a cytotoxic proteoglycan using callus culture of saffron corms (Crocus sativus L.). J. Biotechnol. 73: 53-59.

Everett R.F. 2006. Esau's Plant Anatomy. $3^{\text {rd }}$ Ed. John Wiley and Sons Inc., New Jersey.

Fakhrai F., Evans P.K. 1990. Morphogenic potential of cultured floral explants of Crocus sativus L. for the in vitro production of saffron. J. Exp. Bot. 41: 47-52.

Falagas M.E., McDermott L., Snydman D.R. 1997. Effect of $\mathrm{pH}$ on in vitro antimicrobial susceptibility of the Bacteroides fragilis group. Antimicrob. Agents Chemother. 41: 2047-2049.

Falkiner F.R. 1988. Strategy for the selection of antibiotics for use against common bacterial pathogens and endophytes of plants. Acta Hortic. 225: 53-57.

Falkiner F.R. 1990. The criteria for choosing an antibiotic for control of bacteria in plant tissue culture. Int. Assoc. Plant Tissue Cult. Newslett. 60: 13-23.

Fiori M., Ligios V., Schiaffino A. 2011. Identification and characterization of Burkholderia isolates obtained from bacterial rot of saffron (Crocus sativus L.) grown in Italy. Phytopathol. Mediterr. 50: 450-461.

Frais S., Ng Y.-L., Gulabivala K. 2001. Some factors affecting the concentration of available chlorine in commercial sources of sodium hypochlorite. Int. Endodontic J. 34: 206-215.

Gangopadhyay M., Chakraborty D., Dewanjee S., Bhattacharya S. 2010. Clonal propagation of Zephyranthes grandiflora using bulbs as explants. Biol. Plant. 54: 793-797.

Gantait S., Vahedi M. 2015. In vitro regeneration of high value spice Crocus sativus L.: a concise appraisal. J. Appl. Res. Med. Aromatic Plants 2: 124-133.

George P.S., Visvanath S., Ravishankar G.A., Venkataraman L.V. 1992. Tissue culture of saffron (Crocus sativus L.): somatic embryogenesis and shoot regeneration. Food Biotechnol. 6: 217-223.

Guang P., Shi J.M. 1995. Tissue culture of Crocus corm. J. Guizhou Agric. Coll. 14: 47-49.

Gui Y.L., Xu T.Y., Gu S.R., Liu S.Q., Sun G.D., Zhang Q. 1988. Corm formation of saffron crocus in vitro. Acta Bot. Sin. 30: 338-340.

Han L.L., Zhang X.Y. 1993. Morphogenesis of style stigma like structures from floral explants of Crocus sativus L. and identification of the pigments. Acta Bot. Sin. 35: 157-160.

He K., Yan F., Tang L., Xu Y., Chen F. 2002. Induction of tufty buds from the cormels of saffron and regeneration of cormels. J. Sichuan Univ. (Nat. Sci. Ed.) 39: 1127-1130. /in Chinese with an English abstract/

Homes J., Legros M., Jaziri M. 1987. In vitro multiplication of $C$. sativus L. Acta Hortic. 212: 675-676.

Huang S.Y. 1987. A preliminary study on tissue culture of Crocus sativus. Plant Physiol. Commun. 6: 17-19. /in Chinese/

Husaini A.M., Hassan B., Ghani M.Y., Teixeira da Silva J.A., Kirmani R.A. 2010. Saffron (Crocus sativus Kashmirianus) cultivation in Kashmir: practices and problems. Funct. Plant Sci. Biotechnol. 4: 108-115.

Ilahi I., Jabeen M., Firdous N. 1987. Morphogenesis with saffron tissue cultures. J. Plant Physiol. 128: 227-232.

Jerzy M., Krzymińska A. 2005. Propagation of ornamental plants in vitro. In: Vegetative Propagation of Ornamental Plants. Poznań, pp. 83-105. /in Polish/

Jia Y.J., Chen F., Lin H.H., Cao Y.L., Li Y., Wang S. 1996. Induction of style-stigma-like structure and regeneration of plantlets from corm of Crocus sativus in vitro. J. Sichuan Univ. (Nat. Sci.
Ed.) 33: 747-750. /in Chinese with an English abstract/

Jun Z., Xiaobin C., Fang C. 2007. Factors influencing in vitro flowering from styles of saffron. Acta Hortic. 739: 313-320. Authors' note: The listed authors, as listed by the ISHS, are incorrect (first and family names are inverted)

Kalha C.S., Gupta V. 2009. Saffron 'a legendary crop' - an overview. Plant Dis. Res. 24: 71-72.

Kanchanapoom K., Ponpiboon T., Wirakiat W., Kanchanapoom K. 2011. Regeneration of lily (Lilium longiflorum 'Easter lily') by callus derived from leaf explants cultured in vitro. ScienceAsia 37: 373-376.

Karamian R.2004. Plantlet regeneration via somatic embryogenesis in four species of Crocus. Acta Hortic. 650: 253-259.

Karaoğlu C., Çöcü S., İpek A., Parmaksız I., Uranbey S., Sarıhan E., Arslan N., Kaya M.D., Sancak C., Özcan S., Gürbüz B., Mirici S., Er C., Khawar K.M. 2007. In vitro micropropagation of saffron. Acta Hortic. 739: 223-228.

Koyama A., Ohmori Y., Fujioka N., Miyagawa H., Yamasaki K., Kohda H. 1988. Formation of stigma-like structures and pigments in cultured tissues of Crocus sativus. Planta Med. 54: 375-376.

Kozak D.,Stelmaszczuk M.2013.Comparison of Allium aflatunense B. Fedtsch. 'Purple Sensation' and Allium karataviense Regel. 'Ivory Queen' regenerative capabilities in tissue culture. Acta Sci. Pol. Hortorum Cultus 12: 197-213.

Kulus D. 2014. Micropropagation of Kalanchoe tubiflora (Harvey) Hamet. Science Nature Technologies Nauka Przyroda Technologie 14: 1-8.

Langens-Gerrits M., Alberts M., De Klerk G.J. 1998. Hot-water treatment before tissue culture reduces initial contamination in Lilium and Acer. Plant Cell Tissue Org. Cult. 52: 75-77.

Lapadatescu S., Petolescu C., Furdi F., Lazar A., Velicevici G., Danci M., Bala M. 2013. In vitro regeneration of Crocus sativus L. J. Hortic. For. Biotechnol. 17: 244-247.

Leifert C., Waites W.M. 1994. Dealing with microbial contaminants in plant tissue and cell culture: hazard analysis and critical control points. In: Lumsden P.J., Nicholas J.R., Davies W.J. (eds) Physiology, Growth and Development of Plants in Culture. Springer Netherlands, pp. 363-378.

Liu X.H., Diao J.W., Zhang J.Y., Lu YM. 2012. In vitro micropropagation of Longiflorum - Asiatic (LA) hybrids lily (Lilium) cultivar 'Eyeliner'. African J. Biotechnol. 11: 1350613517.

Liu Q., Liu G. 2010. Commercial micropropagation of ornamental plants in China. Chronica Hortic. 50: 16-20.

Liu Y.M., Tan F., Li K.P. 1995. The tissue culture and plant regeneration of Crocus sativus. J. Southwest China Normal Univ. (Nat. Sci.) 20: 183-186. /in Chinese with an English abstract/

Loskutov A.V., Beninger C.W., Ball T.M., Hosfield G.L., Nair M., Sink A.C. 1999. Optimization of in vitro conditions for stigma-like-structure production from half-ovary explants of Crocus sativus L. In Vitro Cell. Dev. Biol. Plant 35: 200-205.

Lu C.X., Cen X.Y., Wei P.X. 2005. Sterilization induction of lily bulbs. Guangxi Trop. Agric. 97: 12-14. /in Chinese/

Lu W.L., Tong X.R., Zhang Q., Gao W.W. 1992. Study on in vitro regeneration of style-stigma-like structure in Crocus sativus L. Acta Bot. Sin. 34: 251-256. /in Chinese with an English abstract/

Ma X., Gang D.R. 2006. Metabolic profiling of in vitro micropropagated and conventionally greenhouse grown ginger (Zingiber officinale). Phytochemistry 67: 2239-2255. 
Majourhat K., Fernández J.A., Martínez-Gómez P., Piqueras A. 2007. Enhanced plantlet regeneration from cultured meristems in sprouting buds of saffron corms. Acta Hortic. 739: 275-278.

Marinescu M.V., Teodorescu A., Şuțan N.A. 2013. Preliminary results on the in vitro propagation by leaf explants and axillary buds of Iris aphylla L. J. Hortic. For. Biotechnol. 17: 279-282.

Melnyk J.P., Wang S.N., Marcone M.F. 2010. Chemical and biological properties of the world's most expensive spice: saffron. Food Res. Int. 43: 1981-1989.

Mir J.I., Ahmed N., Shafi W., Rashid R., Khan M.H., Sheikh M.A., Shah U.N., Zaffar S., Rather I. 2014. In vitro development and regeneration of saffron (Crocus sativus L.). African J. Biotechnol. 13: 2637-2640.

Mir J.I., Ahmed N., Wani S.H., Rashid R., Mir H., Sheikh M.A. 2010. In vitro development of microcorms and stigma like structures in saffron (Crocus sativus L.). Physiol. Mol. Biol. Plants 16: 369-373.

Mir J.I., Ahmed N., Singh D.B., Shafi W., Wani S.H., Zaffer S. 2015. In-vitro stigma like structure and stigma development in saffron. Vegetos 28: 55-58.

Namera A., Koyama A., Fujioka N., Yamasaki K., Kohda H. 1987. Formation of stigma-like structure and pigments in cultured tissues of Crocus sativus 2. Japanese J. Pharmacognosy 41: 260-262.

Namin M.H., Ebrahimzadeh H., Ghareyazie B., Radjabian T., Gharavi S., Tafreshi N. 2009. In vitro expression of apocarotenoid genes in Crocus sativus L. African J. Biotechnol. 8: 5378-5382.

Namin M.H., Ebrahimzadeh H., Ghareyazie B., Radjabian T., Namin H.H. 2010. Initiation and origin of stigma-like structures (SLS) on ovary and style explants of saffron in tissue culture. Acta Biol. Cracov. Ser. Bot. 52: 55-60.

Ndong Y.A., Wadouachi A., Sangwan-Norreel B.S., Sangwan R.S. 2006. Efficient in vitro regeneration of fertile plants from corm explants of Hypoxis hemerocallidea landrace Gaza - the "African Potato". Plant Cell Rep. 25: 265-273.

Nesi B., Lazzereschi S., Pecchioli S., Grassotti A., Rizzo D., Stefani L., Paoli M., Della Bartola M., Materazzi A. 2013. Detection of viruses infecting Lilium spp. by RT-PCR and Real-Time PCR. Acta Hortic. 1002: 215-221.

Nesi B., Trinchello D., Lazzereschi S., Grassotti A. 2009. Production of lily symptomless virus-free plants by shoot meristem tip culture and in vitro thermotherapy. HortScience 44: 217-219.

Pandey R.K., Singh A.K., Sharma M. 2009. In vitro propagation of Lilium. Biological Forum 1: 26-28.

Newton W., Hastings R.J., Bosher J.E. 1933. Sterilization of narcissus bulbs by immersion in silver nitrate - potassium cyanide solution in vacuo. Can. J. Res. 9: 31-36.

Ngezahayo E., Liu B. 2014. Axillary bud proliferation approach for plant biodiversity conservation and restoration. Int. J Biodiv. 2014: 1-9.

Parray J.A., Kamili A.N., Hamid R., Husaini A.M. 2012. In vitro cormlet production of saffron (Crocussativus L. Kashmirianus) and their flowering response under greenhouse. GM Crops Food 3: 289-295.

Pen H.J., Hu R.H. 2014. Optimization conditions of tissue culture of Crocus sativus L. using orthogonal experiment. Northern Hortic. 6: 111-114. /in Chinese with an English abstract/

Piqueras A., Han B.H., Escribano J., Rubio C., Hellin E., Fernández J.A. 1999. Development of cormogenic nodules and microcorms by tissue culture, a new tool for the multiplication and genetic improvement of saffron. Agronomie 19: 603-610.

Plessner O., Ziv M., Negbi M., 1990. In vitro corm production in the saffron (Crocus sativus L.). Plant Cell Tissue Organ Cult. 20: 89-94.

Podwyszyńska M. 2015. The mechanism of in vitro storage organ formation in ornamental geophytes. Floric. Ornam. Biotechnol. 6: 9-23.

Podwyszyńska M., Marasek A. 2003. Effects of thidiazuron and peclobutrazol on regeneration potential of tulip flowers stalk explants in vitro and subsequent shoot multiplication. Acta Soc. Bot. Pol. 72: 181-190.

Purohit S.D., Teixeira da Silva J.A., Habibi N. 2011. Current approaches for cheaper and better micropropagation technologies. Int. J. Plant Dev. Biol. 5: 1-36.

Quadri R.R., Kamili A.N., Shah A.M., Husaini A.M., Teixeira da Silva J.A. 2010. In vitro studies on cormogenesis and maximization of corm size in saffron. Funct. Plant Sci. Biotechnol. 4 (Special Issue 2): 132-135.

Raja W., Zaffer G., Wani S.A. 2007. In vitro microcorm formation in saffron (Crocus sativus L.). Acta Hortic. 739: 291-296.

Rajabpoor Sh., Azghandi A.V., Saboora A. 2007. Effects of different concentrations of 2,4-D and BAP on somatic embryogenesis induction in saffron (Crocus sativus L.). Pak. J. Biol. Sci. 10: 3927-3930.

Reed B., Tanprasert P. 1995. Detection and control of bacterial contaminants of plant tissue cultures. A review of recent literature. Plant Tissue Cult. Biotechnol. 3: 137-142.

Renau-Morata B., Moyá L., Nebauer S.G., Seguí-Simarro J.M., Parra-Vega V., Gómez M.D., Molina R.V. 2013. The use of corms produced under storage at low temperatures as a source of explants for the in vitro propagation of saffron reduces contamination levels and increases multiplication rates. Ind. Crops Prod. 46: 97-104.

Sano K., Himeno H. 1987. In vitro proliferation of saffron (Crocus sativus L.) stigma. Plant Cell Tissue Organ Cult. 11: 159-166.

Sarma K.S., Maesato K., Hara T., Sonoda Y. 1990. In vitro production of stigma-like structures from stigma explants of Crocus sativus L. J. Exp. Bot. 41: 745-748.

Sarma K.S., Sharada K., Maesato K., Hara T., Sonoda Y. 1991. Chemical and sensory analysis of saffron produced through cultures of Crocus sativus. Plant Cell Tissue Organ Cult. 26: 11-16.

Seabrook J.E.A., Farrell G. 1993. City water can contaminate tissue culture stock plants. HortScience 28: 628-629.

Schmiedel P., von Rybinski W. 2006. Applied theory of surfactants. In: Farn R.J. (ed) Chemistry and Technology of Surfactants. Blackwell Publishing, Oxford, pp. 46-91.

Shahabzadeh Z., Heidari B., Dadkhodaie A. 2013. Regenerating salt tolerant saffron (Crocus sativus) using tissue culture with increased pharmaceutical ingredients. J. Crop Sci. Biotechnol. 16: 209-217.

Sharafzadeh S. 2012. In vitro callus induction in saffron leaves. Int. J. Pharm. Biol. Sci. 3: 171-175.

Sharan M., Dhumne I.L., Sharon M. 2010. Micropropagation of Chlorophytum borivilliens through direct organogenesis. Adv. Appl. Sci. Res. 1: 41-46.

Sharifi G., Ebrahimzadeh H. 2010a. Changes of antioxidant enzyme, activities and isoenzyme profiles during in vitro shoot formation in saffron (Crocus sativus L.). Acta Biol. Hung. 61: 73-89.

Sharifi G., Ebrahimzadeh H., Ghareyazie B., Karimi M. 2010 b. Globular embryo-like structures and highly efficient 
thidiazuron-induced multiple shoot formation in saffron (Crocus sativus L.). In Vitro Cell. Dev. Biol. Plant 46: 274-280.

Sharifi G., Ebrahimzadeh H., Ghareyazie B., Gharechahi J., Vatankhah E.2012. Identification of differentially accumulated proteins associated with embryogenic and non-embryogenic calli in saffron (Crocus sativus L.). Proteome Sci. 10: 3.

Sharma K.D., Singh B.M., Sharma T.R., Rathour R., Sharma R., Goel S. 2005. Development of low-cost media for in vitro shoot regeneration in saffron (Crocus sativus L.). Indian Perfumer 49: 333-337.

Sharma K.D., Rathour R., Sharma R., Goel S., Sharma T.R., Singh B.M. 2008. In vitro cormlet development in Crocus sativus. Biol. Plant. 52: 709-712.

Sheibani M., Azghandi A.V., Nemati S.H. 2007a. Induction of somatic embryogenesis in saffron using thidiazuron (TDZ). Pak. J. Biol. Sci. 10: 3564-3570.

Sheibani M., Nemati S.H., Davarinejad G.H., Azghandi A.V., Habashi A.A. 2007b. Induction of somatic embryogenesis in saffron using thidiazuron (TDZ). Acta Hortic. 739: 259-268.

Sivanesan I., Jana S., Jeong R.R. 2014. In vitro shoot regeneration and microcorm development in Crocus vernus (L.) Hill. Pak. J. Bot. 46: 693-697.

Tang L., Xu Y., Zhao T.T., Yan F., Xu S.X., Chen F. 2004. Transient expression of gus gene via particle bombardment in Crocus sativus L. J. Beijing For. Univ. 26: 35-38. /in Chinese with an English abstract/

Teixeira da Silva J.A. 2012a. Is BA (6-benzyladenine) BAP (6-benzylaminopurine)? Asian Australasian J. Plant Sci. Biotechnol. 6 (special issue 1): 121-124.

Teixeira da Silva J.A. 2012b. Callus, calluses or calli: multiple plurals? Asian Australasian J. Plant Sci. Biotechnol. 6 (special issue 1): $125-126$.

Teixeira da Silva J. A. 2014. Novel factors affecting shoot culture of chrysanthemum (Dendranthema $\times$ grandiflora). Bot. Lithuanica 20: 27-40.

Teixeira da Silva, J.A. 2015. Negative results: negative perceptions limit their potential for increasing reproducibility. J. Negative Results BioMed. 14: 12.

Teixeira da Silva J.A., Dobránszki J. 2013. How timing of sampling can affect the outcome of the quantitative assessment of plant organogenesis. Sci. Hortic. 159: 59-66.

Teixeira da Silva J.A. Dobránszki J. 2016. Tissue culture of Muscari species: a review. Rendiconti Lincei 27: 427-441.

Teixeira da Silva J.A., Winarto B., Dobránszki J., Cardoso J.C., Zeng S.J. 2016. Tissue disinfection for preparation of Dendrobium in vitro culture. Folia Hortic. 28: 57-75.

Teixeira da Silva J.A., Winarto B., Dobranszki J., Zeng S. 2015. Disinfection procedures for in vitro propagation of Anthurium. Folia Hortic. 27: 3-14.

Tymoszuk A. 2014. Application of silver and copper nanocolloids in disinfection of explants in chrysanthemum in vitro cultures. Nanotechnologia PL 2014 Conference, pp. 47-48.

Tymoszuk A. 2015. Application of silver and copper nanocolloids in disinfection of explants in chrysanthemum in vitro cultures. 7th Polish Conference on Nanotechnology. Book of Abstracts, pp. 222.

Vahedi M., Kalantari S., Salami S.A. 2014. Factors affecting callus induction and organogenesis in saffron (Crocus sativus L.). Plant Tissue Cult. Biotechnol. 24: 1-9.

Vahedi M., Kalantari S., Salami S.A. 2015. Effects of osmolytic agents on somatic embryogenesis of saffron (Crocus sativus L.). Notulae Sci. Biol. 7: 57-61.
Vatankhah E., Niknam V., Ebrahimzadeh H., 2010. Activity of antioxidant enzyme during in vitro organogenesis in Crocus sativus. Biol. Plant. 54: 509-514.

Vatankhah E., Niknam V., Ebrahimzadeh E. 2014. Histological and biochemical parameters of Crocus sativus during in vitro root and shoot organogenesis. Biol. Plant. 58: 201-208.

Wang C.G., Chen Fang. 2000. Study on in vitro regeneration of style-stigma like structure in Crocus chrysanthus advance. J Sichuan Univ. (Nat Sci. Ed.) 37: 144-146.

Wang L., Li X.W., Lou Y.X., Liu K.F., Wang Y.F. 2006. The preliminary study on the tissue culture of the Crocus sativus L. J. Henan Univ. Chin. Med. 21: 30-31. /in Chinese with an English abstract/

Wang S.Q., Zhao Y.Q., Liu L.S., Guo Y.D. 2011. Callus induction and plant regeneration of saffron. Southwest China J. Agric. Sci. 24: 369-372. /in Chinese with an English abstract/

Wang X.G., Xiao J.M. 2012. Tissue culture and rapid regeneration of saffron. Shanghai Agric. Sci. Technol. 5: 93-95. /in Chinese/

Wang Y., Han T., Zhu Y., Wu J.Z., Guo L., Li L., Qing L.P. 2009. Study on tissue culture and rapid regeneration of saffron. Chinese Trad. Herbal Drugs 40: 807-809. /in Chinese/

Winarto B., Teixeira da Silva J.A. 2012a. Sterilization procedure for in vitro culture of lether leaf fern (Rumohra adiantiformis). Int. J. Plant Dev. Biol. 6: 46-50.

Winarto B., Teixeira da Silva J.A. 2012b. Improved micropropagation protocol for leatherleaf fern (Rumohra adiantiformis) using rhizomes as donor explant. Sci. Hortic. 140: 74-80.

World Health Organization. 2000. Disinfectants and disinfection by-products. Env. Health Criteria 216. Geneva.

Yadav R., Yadav N., Pal M., Goutam, U. 2013. Multiple shoot proliferation, bulblet induction and evaluation of genetic stability in Asiatic hybrid lily (Lilium sp.). Indian J. Plant Physiol. 18: 354-359.

Yang B.M., Huang Y.L., Xu W.J, Bao L.X. 2015. Explant selection and cluster buds induction in vitro of saffron (Crocus sativus L.). Agric. Sci. Technol. Commun. 2: 106-108.

Yang J.X., Miao S.X. 1984. Corm induction in vitro of saffron. Medic. Sci. Technol. 6: 1-2.

Yang Y.H., Lu J., Ma J.P. 1996. Studies on callus induction and cell culture of saffron. Biotechnology 6:15-17. /in Chinese with an English abstract/

Yasmin S., Nehvi F.A. 2014a. In vitro microcorm formation in saffron (Crocus sativus L.). J. Cell Tissue Res. 14: 4463-4470.

Yasmin S., Nehvi FA. 2014b. Effect of plant growth regulators on microcorm formation in saffron (Crocus sativus L.). Int. J. Curr. Microbiol. Appl. Sci. 3: 702-712.

Yasmin S., Nehvi F.A., Wani S.A. 2013. Tissue culture as an alternative for commercial corm production in saffron: A heritage crop of Kashmir. African J. Biotechnol. 12: 3940-3946.

Yildiz M. 2012. The prerequisite of the success in plant tissue culture: high frequency shoot regeneration. In: Leva A., Rinaldi L.M.R. (eds.) Agricultural and Biological Sciences Recent Advances in Plant in Vitro Culture. In Tech, Rijeka, pp. 73-77.

Yuan L.H., Lu Y.T., Huang J. 2009. Callus induction and browning inhibition of Crocus sativus L. J. Nanjing Univ. Technol. (Nat. Sci.Ed.) 31: 21-26. /in Chinese with an English abstract/

Zaffar G., Ahmad M., Shahida I., Razvi S.M., Habib M., Ahmad A. 2014. Effect of paclobutrazol and sucrose on in vitro corm formation in saffron (Crocus sativus). J. Cell Tissue Res. 14: 4069-4072. 
Zamora A.B., Gruezo S.S. 1999. Shoot culture and regeneration in Benguet lily (Lilium philippinensis). Philippine J. Crop Sci. 24: 85-89.

Zeng Y., Yan F., Tang L., Chen F. 2003. Increased crocin production and induction frequency of stigma-like- structure from floral organs of Crocus sativus by precursor feeding. Plant Cell Tissue Organ Cult. 72: 185-191.

Zeybek E., Önde S., Kaya Z. 2012. Improved in vitro micropropagation methods with adventitious corms and roots for endangered saffron. Central Eur. J. Biol. 7: 138-145.

Zhang J., Lin C.L., Wang L.C., Liang G.L. 2007. Study on tissue culture of saffron corms. J. Southwest China Normal Univ. (Nat. Sci.Ed.) 32: 68-72. /in Chinese with an English abstract/

Zhao J., Chen F., Yan F., Tang L., Xu Y. 2001a. In vitro regeneration of style-stigma-like structure from stamens of Crocus sativus.
Acta Bot. Sin. 43: 475-479.

Zhao J., Xu Y., Yan F., Tang L., Chen F. 2001b. Induction of callus and subculture and suspension culture of style callus of saffron (Crocus sativus L.). J. Sichuan Univ. (Nat. Sci. Ed.) 38: 421-424.

Zhao T.T., Tang L., Xiao H.B., Yan C., Chen F. 2005. Optimization on regeneration conditions of style-stigma-like structure in Crocus sativus L. J. Sichuan Univ. (Nat. Sci. Ed.) 42: 1238-1242. /in Chinese with an English abstract/

Zhao T.T., Tang L., Xu Y., Yan F., Chen F. 2005b. In vitro flowering of Crocus sativus. Plant Physiol. Commun. 41: 64. /in Chinese/

Zhu B.H. 2009. Rapid propagation and virus-free plant cultivating of Crocus sativus L. MSc thesis, Chongqing: Southwest University, China, pp. 46. /in Chinese with an English abstract/ 